\title{
Article
}

\section{Novel Chitosan-Silica Hybrid Hydrogels for Cell Encapsulation and Drug Delivery}

\author{
Soher N. Jayash ${ }^{1, * \mathbb{D}}$, Paul R. Cooper ${ }^{2}$, Richard M. Shelton ${ }^{1}$, Sarah A. Kuehne ${ }^{1} \mathbb{D}$ \\ and Gowsihan Poologasundarampillai ${ }^{1, * \text { (D) }}$ \\ 1 School of Dentistry, University of Birmingham, 5 Mill Pool Way, Edgbaston, Birmingham B5 7EG, UK; \\ R.M.Shelton@bham.ac.uk (R.M.S.); S.A.Kuehne@bham.ac.uk (S.A.K.) \\ 2 Department of Oral Sciences, Sir John Walsh Research Institute, Faculty of Dentistry, University of Otago, \\ P.O. Box 56, Dunedin 9054, New Zealand; P.Cooper@otago.ac.nz \\ * Correspondence: soheernaji20@yahoo.com or s.jayash@bham.ac.uk (S.N.J.); \\ G.Poologasundarampillai@bham.ac.uk (G.P.)
}

Citation: Jayash, S.N.; Cooper, P.R.;

Shelton, R.M.; Kuehne, S.A.;

Poologasundarampillai, G. Novel

Chitosan-Silica Hybrid Hydrogels for Cell Encapsulation and Drug Delivery. Int. J. Mol. Sci. 2021, 22, 12267.

https://doi.org/10.3390/

ijms222212267

Academic Editor: Magali Cucchiarini

Received: 10 October 2021

Accepted: 8 November 2021

Published: 12 November 2021

Publisher's Note: MDPI stays neutral with regard to jurisdictional claims in published maps and institutional affiliations.

Copyright: () 2021 by the authors. Licensee MDPI, Basel, Switzerland. This article is an open access article distributed under the terms and conditions of the Creative Commons Attribution (CC BY) license (https:/ / creativecommons.org/licenses/by/ $4.0 /)$.
Abstract: Hydrogels constructed from naturally derived polymers provide an aqueous environment that encourages cell growth, however, mechanical properties are poor and degradation can be difficult to predict. Whilst, synthetic hydrogels exhibit some improved mechanical properties, these materials lack biochemical cues for cells growing and have limited biodegradation. To produce hydrogels that support 3D cell cultures to form tissue mimics, materials must exhibit appropriate biological and mechanical properties. In this study, novel organic-inorganic hybrid hydrogels based on chitosan and silica were prepared using the sol-gel technique. The chemical, physical and biological properties of the hydrogels were assessed. Statistical analysis was performed using One-Way ANOVAs and independent-sample $t$-tests. Fourier transform infrared spectroscopy showed characteristic absorption bands including amide II, Si-O and Si-O-Si confirming formation of hybrid networks. Oscillatory rheometry was used to characterise the sol to gel transition and viscoelastic behaviour of hydrogels. Furthermore, in vitro degradation revealed both chitosan and silica were released over 21 days. The hydrogels exhibited high loading efficiency as total protein loading was released in a week. There were significant differences between $\mathrm{TC}_{2} \mathrm{G}$ and $\mathrm{C}_{2} \mathrm{G}$ at all-time points $(p<0.05)$. The viability of osteoblasts seeded on, and encapsulated within, the hydrogels was $>70 \%$ over $168 \mathrm{~h}$ culture and antimicrobial activity was demonstrated against Pseudomonas aeruginosa and Enterococcus faecalis. The hydrogels developed here offer alternatives for biopolymer hydrogels for biomedical use, including for application in drug/cell delivery and for bone tissue engineering.

Keywords: chitosan; thiolated chitosan; organic-inorganic hybrid hydrogel; sol-gel process; cell encapsulation; drug delivery

\section{Introduction}

Skeletal tissue defects resulting from disease, congenital deformities or trauma are often treated by surgery using autografts, allografts and/or xenografts. Autografts harvested from the patient remain the gold standard but are limited by availability and donor site morbidity [1]. While allografts and xenografts are readily available in sufficient quantity these materials may cause risk of infection transmission, unpredictable bone formation and immunogenic responses [2-4]. Tissue engineering and regenerative medicine approaches have been proposed to develop implantable graft constructs that are as potent as autografts but overcome current limitations [5]. Natural polymer hydrogels that imitate the extracellular matrix (ECM) of tissues are promising materials for the therapeutic delivery of drugs, proteins and cells for tissue repair and regeneration [6,7]. Injectability of such hydrogel systems also allows for minimally invasive surgery to fill defects $[8,9]$.

Different types of hydrogels are being developed and constructed from natural or synthetic materials. Hydrogels made from naturally derived biopolymers, such as col- 
lagen, hyaluronic acid and gelatin, were the first to be identified as having the potential to mimic the ECM [10]. Also, chitosan based hydrogels were shown to enhance new bone formation [11]. These naturally derived hyrogels have physiochemical advantages including the provision of an aqueous environment that is not cytotoxic and enables cell proliferation. However, these gels exhibit poor mechanical strength (e.g., both compressive and tensile) and batch-to-batch variation which makes production and optimisation challenging [12-14]. Conversely, synthetic hydrogels based on polyethylene glycol (PEG) have enhanced mechanical strength compared with naturally derived hydrogels which provides stability to support cells during 3D culture [15]. However, relatively slow degradation may be a limitation [16] as well as the lack of ligand chemistry to enable cell instructive signals $[17,18]$. Peptide-based hydrogels overcome many of these problems and consequently have attracted significant interest in the biomedical field, although suffer from various drawbacks, including solubility issues, burst release, low bioavailability due to high clearance or metabolism, enhanced degradation and nonspecific distribution $[19,20]$. There is a serious need for new hydrogel biomaterials with suitable mechanical and biochemical properties to support cells in a 3D environment and address these issues.

Hybrid materials with molecularly interpenetrating networks of organic and inorganic phases can be classified based on the type of bonding present between the different moieties [21]. Covalently crosslinked hybrids (Class II), the degree of crosslinking and the proportion of organic to inorganic components, provide excellent control of mechanical properties and degradation behaviour [22-24]. Hybrid materials for biomedical applications often employ a natural polymer which presents ligands that provide biochemical cues for cells [25], whilst, silica derived from organosilanes forms the inorganic component. Due to the diversity of natural polymers and the versatility of organosilane chemistry, many types of hybrid materials have been developed for biomedical applications [26-29]. Incorporation of silica in hybrid hydrogels leads to the formation of a physical network and increases the strength of adsorption of polymer network that will be important for the mechanical properties, as both physical adsorption and chemical covalent bonds are present. Such chemically cross-linked gels containing polymers on silica nanoparticle materials provide a generic route for improving hydrogel properties [30,31]. Chitosan-silica hybrids show much promise due to being biodegradable, non-antigenic, nontoxic and promoting certain biological processes $[32,33]$. Furthermore, chitosan can be functionalised with 2-iminothiolane hydrochloride to produce thiolated chitosan (TC) with thiol functional side groups [34] which serve to improve permeation and mucoadhesive properties of chitosan. Hydrogen bonding and hydrophobic interactions also play important roles in the mucoadhesion of chitosan. The enhancement in mucoadhesion is based on the formation of disulfide bridges with mucus glycoproteins and the formation of covalent bonds between the polymer and the mucus layer [34-38].

Organic-inorganic hybrids have previously been synthesised using alkoxysilanes as the inorganic precursors, most notably tetraethoxysilane (TEOS) [39-41]. These undergo sol to gel transition releasing ethanol when reacted in acidic or alkaline aqueous solutions. Ethanol is a denaturant, thus hybrid hydrogels intended for delivery of therapeutics and/or cell encapsulation cannot be synthesised using alkoxysilanes. Non-cytotoxic inorganic precursors that undergo sol to gel transition within physiologically benign conditions are therefore desirable [42,43]. Synthetic 3D materials are required as grafts for clinical applications to regenerate healthy tissues by combating infection, promoting vascularisation, accelerating wound healing and bone formation. This work produced a novel synthetic graft platform for use in tissue engineering by developing advanced organicinorganic hybrid biomaterials. Organic-inorganic hybrid hydrogels were developed using the 'soft-chemistry' sol-gel process to take advantage of the physiochemical properties of the biopolymers. The predictable and tuneable nature of synthetic silica materials allows 'dial-in' degradation, bioactivity and mechanical properties via the manipulation of relative chitosan/bioactive-silica compositions and the strength of interactions. Also, this study presents the development and characterisation of novel chitosan-silica hybrid hydrogels 
employing polyol-modified silanes, providing a new class of biologically suitable silica precursor for bone tissue engineering.

\section{Results}

Organic-inorganic hybrid hydrogels with covalent crosslinking employing GPTMS were produced. These were labelled as $\mathrm{C}$-chitosan, TC-thiolated chitosan and $\mathrm{C}_{1} \mathrm{G}$, $\mathrm{C}_{2} \mathrm{G}$ and $\mathrm{C}_{10} \mathrm{G}$ or $\mathrm{TC}_{1} \mathrm{G}, \mathrm{TC}_{2} \mathrm{G}$ and $\mathrm{TC}_{10} \mathrm{G}$ representing chitosan or thiolated chitosan crosslinked with 1 mole of GPTMS for $X$ moles of glucosamine monomer. Increasing $X$ gives decreasing crosslinking.

\subsection{Functionalisation of Chitosan and Characterisation of the Hybrid Structure}

Functionalisation of chitosan with GPTMS and the possible structures that could form are illustrated in Figure 1a,b. The hydrogels fabricated with the various components were investigated using FTIR and ${ }^{1} \mathrm{H}$ NMR. Bands corresponding with amide I ( $\mathrm{C}=\mathrm{O}$ : vs. $\left.1600-660 \mathrm{~cm}^{-1}\right)$, amide II (N-H: $\left.\mathrm{v}_{\mathrm{b}} 1470-1590 \mathrm{~cm}^{-1}\right)$, Si-O-Si $\left(\mathrm{v}_{\mathrm{b}} 1060-1180\right)$ and Si-O ${ }^{\mathrm{NBO}}$ $\left(\mathrm{v}_{\mathrm{b}}\right.$ 940-970) (Figure 1c) were used to ascertain the reaction of thiolated chitosan or chitosan with GPTMS [44,45]. FTIR spectra revealed differences between chitosan and thiolated chitosan as Amide I and Amide II bands appeared shifted to higher wavenumbers once thiolated. Furthermore, with an increasing amount of coupling agent in the functionalised polymer $\left(C_{x} G\right.$ and $\left.T_{x} G\right)$ an higher intensity of Si-O-Si and $\mathrm{Si}-\mathrm{O}^{\mathrm{NB}}$ vibrations were observed suggesting an enhanced degree of inorganic silica condensation and crosslinking.
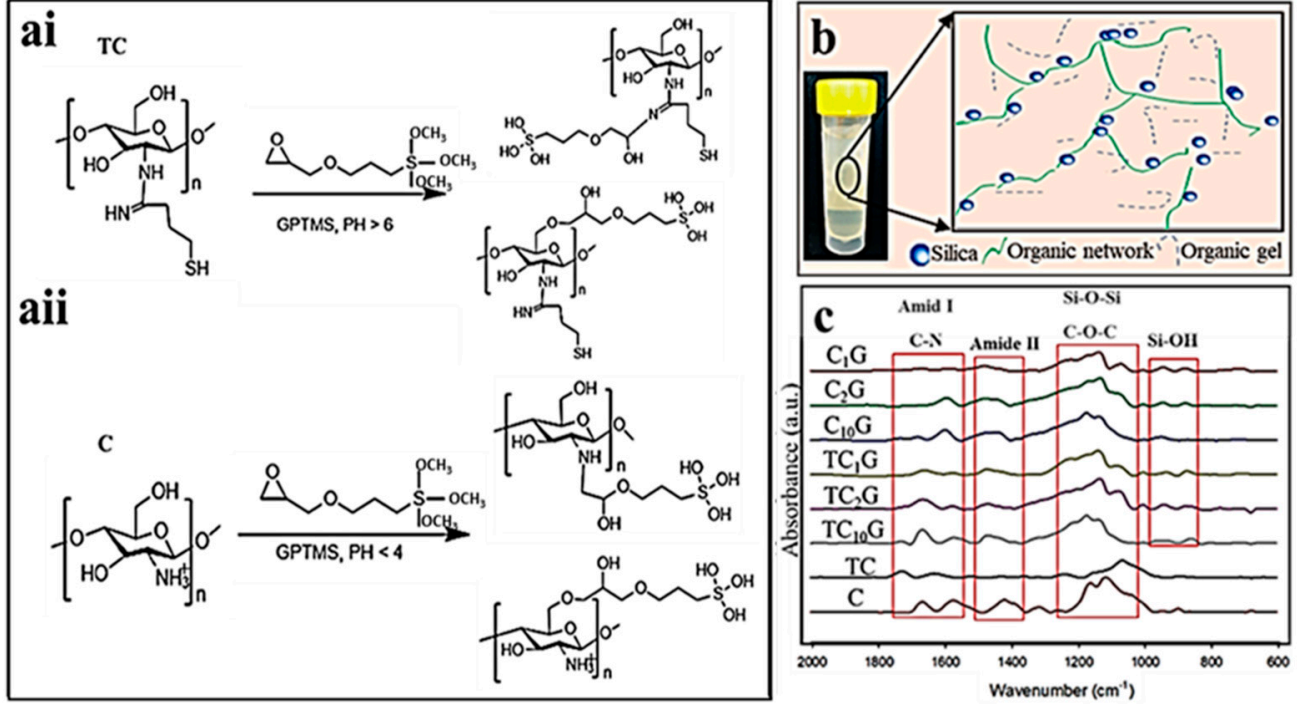

Figure 1. (a) Schematic showing the reaction sequences and the chemical structures of thiolated chitosan (ai) and chitosan (aii) needed for hydrogel preparation. (b) A schematic image of the distribution of globular particles of the branched 3D network of silica and chitosan on the hybrid hydrogel. (c) FTIR spectra of hybrid hydrogels with varying organic/inorganic weight ratios showing amide I and II, Si-O-Si and Si-ONB bands.

${ }^{1} \mathrm{H}$ NMR spectra (Figure 2) for chitosan revealed peaks between 3.0 and $5.0 \mathrm{ppm}$, which were ascribed to the protons of the glucosamine unit $[46,47]$. The peak at $2.1 \mathrm{ppm}$ was due to the protons of the methyl group in the $\mathrm{N}$-acetylglucosamine unit. The sulfhydryl hydrogen was relatively easily replaced by deuterium present within solvent $\mathrm{D}_{2} \mathrm{O}$ in NMR spectra, consequently, the thiol peak was difficult to distinguish in the thiolated chitosan spectrum [48]. However, the new chemical shift corresponding with the proton on the carbon of amine appeared in thiolated chitosan $\left(\delta^{1} \mathrm{H} 2.9 \mathrm{ppm}\right)$. Peaks in GPTMSfunctionalised polymers (chitosan and thiolated chitosan) and GPTMS spectra attributed to protons of the epoxide ring were identified between $\delta^{1} \mathrm{H} 2.9$ and $\delta^{1} \mathrm{H} 2.7 \mathrm{ppm}$ which suggested a large number of epoxides remained intact. In addition, a new peak was 
observed in the $3.5 \mathrm{ppm}$ region, which was attributed to the reaction of the epoxide ring with the primary amine of chitosan to form a secondary amine as previously observed by Connell et al. [49]. ${ }^{1} \mathrm{H}$ NMR also showed the silanes had completely hydrolysed following the functionalisation reaction due to the loss of methyl groups on the GPTMS.

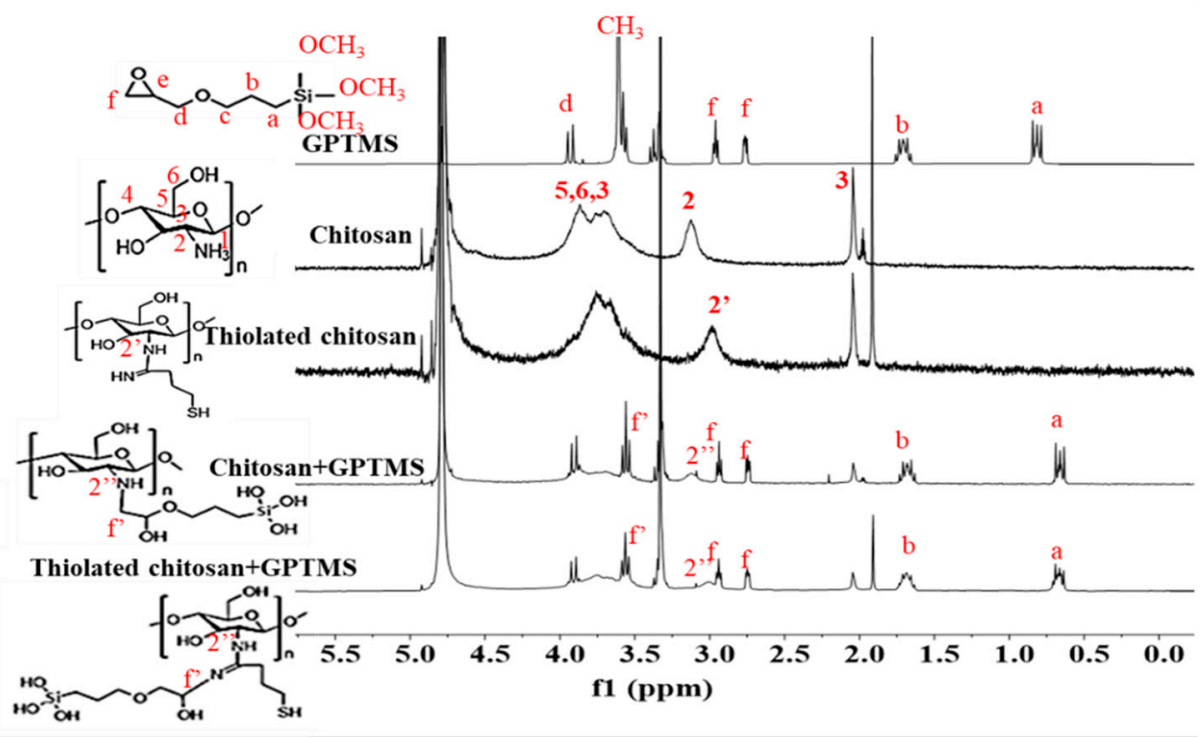

Figure 2. H-NMR spectra of GPTMS and chitosan or thiolated chitosan before and after functionalisation with GPTMS for $24 \mathrm{~h}$ in ratio 1:4.

\subsection{In Vitro Degradation of the Hydrogel}

In vitro biodegradation of hydrogels was studied by monitoring weight loss and analysing substances eluted into PBS with and without lysozyme over time. The degradation rate was the slowest in $\mathrm{C}_{1} \mathrm{G}(<5 \%)$ after $1 \mathrm{~h}$ and in $\mathrm{C}_{2} \mathrm{G}$ after $24 \mathrm{~h}(<30 \%)$ (Supplementary Figure S1). The degradation rates of $\mathrm{C}_{10} \mathrm{G}$ and $\mathrm{TC}_{10} \mathrm{G}$ were more than $70 \%$ at $24 \mathrm{~h}$ and up to $90 \%$ by weight of hydrogel was degraded by 21 days. Hydrogel weightloss after $504 \mathrm{~h}$ showed that $\mathrm{C}_{2} \mathrm{G}$ and $\mathrm{TC}_{2} \mathrm{G}$ had the slowest rate of degradation; consequently, hydrogels with this ratio were selected for further detailed analysis.

Degradation products from the hydrogels were further analyzed. Burst release was observed in the first few days followed by controlled release (Figure 3). Soluble silica concentration as a function of immersion time in PBS was measured using ICP-AES and the degraded organics, glycerol and chitosan (released in the form of glucosamine (GA) and $\mathrm{N}$-acetyl-D-glucosamine (N-Ac-GA)), were quantified using HPLC. The GLMS hydrogel (used as control) was completely degraded or became unstable after 3 days. The quantity of degradation products released from hydrogels in PBS containing lysozyme was greater than in PBS alone. Two modes of silica release from hydrogels were observed, initial burst release, followed by a controlled release. Burst release of silica occurred in the $C_{2} G$ hydrogel at $7 \mathrm{~h}$ while the $\mathrm{TC}_{2} \mathrm{G}$ hydrogel demonstrated a slow release. $\mathrm{TC}_{2} \mathrm{G}$ immersed in PBS demonstrated the slowest rate of Si release, followed by $\mathrm{TC}_{2} \mathrm{G}$ immersed in PBS containing lysozyme where Si release remained at a relatively low level $(0.3 \pm 0.2 \mu \mathrm{g} / \mathrm{mL}$ per day) from 72 to $504 \mathrm{~h}$. The maximum total concentration of silica released at 21 days was $16 \mu \mathrm{g} / \mathrm{mL}$ from $\mathrm{C}_{2} \mathrm{G}$ immersed in PBS with lysozme (supporting information Table S1).

HPLC analysis showed the retention time of glycerol was $2.78 \mathrm{~min}$ while GA and $\mathrm{N}$-Ac-GA derivatives were detected in two peaks between 5 and 8 min compared with standards. The cumulative degradation products of glycerol shown in Figure 3 revealed 3 modes of release, initial burst release, followed by rapid release and then a plateau region. The highest release of glycerol occurred from the GLMS hydrogel within $96 \mathrm{~h}$. Glycerol showed burst release up until $24 \mathrm{~h}$ followed by a controlled release at $189 \mathrm{~h}$ and a plateau profile until $504 \mathrm{~h}$. The glycerol released from the $\mathrm{TC}_{2} \mathrm{G}$ and $\mathrm{C}_{2} \mathrm{G}$ hydrogels in the first 
week occurred rapidly and was responsible for the majority of the weight loss from the hydrogels. The highest accumulated concentration release of glycerol was $1214 \mu \mathrm{g} / \mathrm{mL}$ at 21 days (supporting information Table S2). Chitosan release followed a similar trend to that of silica release (Figure 3) as $\mathrm{TC}_{2} \mathrm{G}$ hydrogels exhibited the slowest release. Chitosan showed burst release until $24 \mathrm{~h}$ followed by controlled release up to $504 \mathrm{~h}$. The highest accumulation concentration released was $10 \mu \mathrm{g} / \mathrm{mL}$ at 21 days. There was a significant difference between chitosan monomers released in enzymatic solution compared with PBS only $(p<0.05)$ in the first hour, after that time-point no significant difference was observed $(p>0.05)$ (supporting information Table S3).

\section{- $\mathrm{C}_{2} \mathrm{GE}+\mathrm{PBS} \square \mathrm{C}_{2} \mathrm{G}$ PBS $\triangle \mathrm{TC}_{2} \mathrm{G} \mathrm{E}+\mathrm{PBS} 0 \mathrm{TC}_{2} \mathrm{G} P B S \times \mathrm{GLMS}$ PBS}

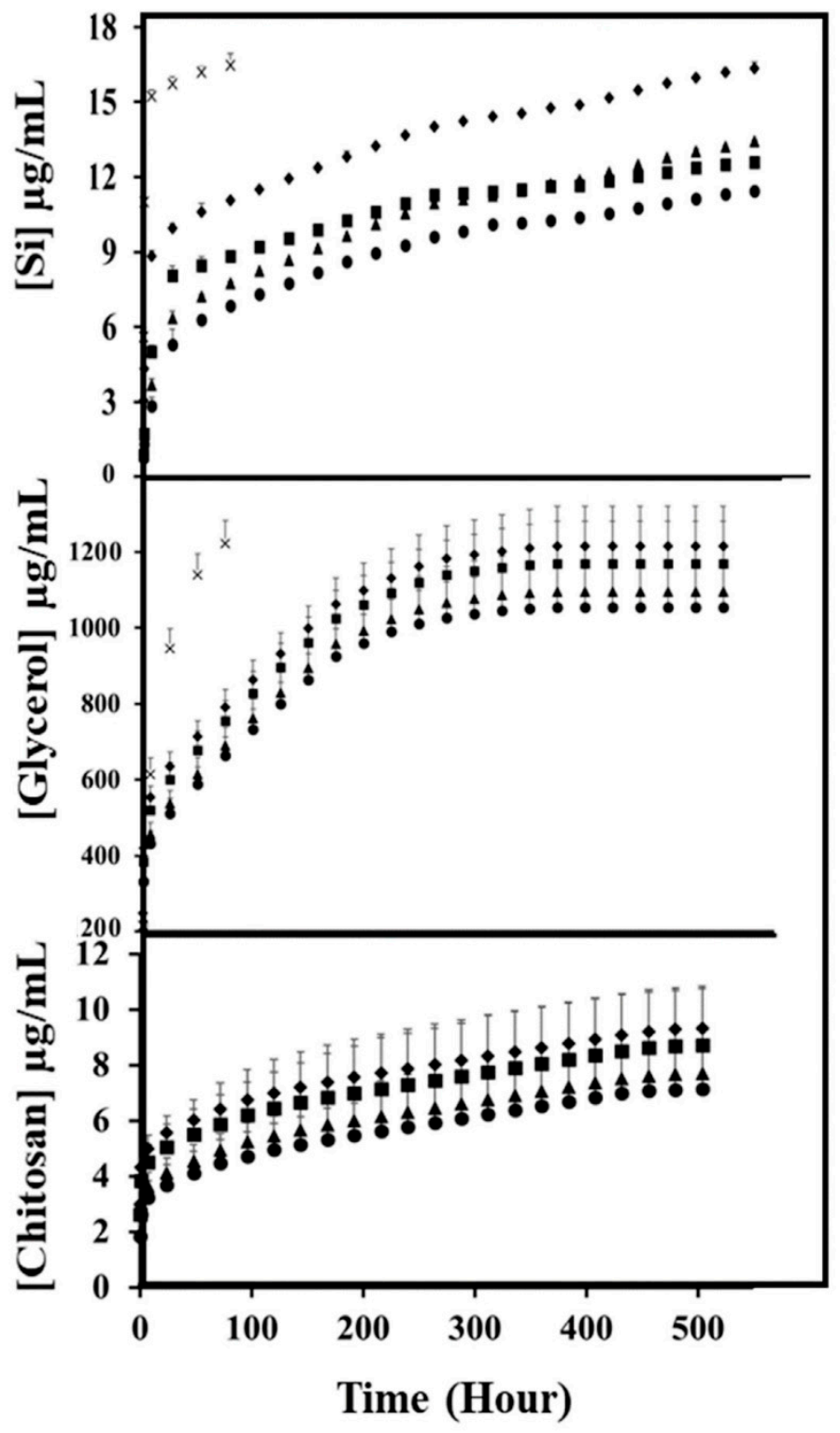

Figure 3. Accumulation of silica, glycerol and chitosan degradation products released in degradation solution of $\mathrm{TC}_{2} \mathrm{G}$ and $\mathrm{C}_{2} \mathrm{G}$ up $504 \mathrm{~h}$. E+PBS: degradation solution containing lysozyme, PBS: only PBS.

\subsection{Rheological Properties of Hybrid Hydrogels}

Viscoelastic properties of the hybrids in liquid and gelled states were measured using a parallel plate oscillation rheometer. The gelling time for hybrids was performed at a constant frequency (10 rad/s) and strain (1\%) sweeps were performed to assess sol to 
gel transition. Chitosan and thiolated-chitosan formulations exhibited low viscosity with thiolated chitosan exhibiting higher viscosity than chitosan. This coincided with a higher loss modulus $\left(G^{\prime \prime}\right)$ than storage modulus $\left(G^{\prime}\right)$ in the liquid state. Both $G^{\prime}$ and $G^{\prime \prime}$ increased rapidly as gelation proceeded; the build-up rate of $G^{\prime}$ was much higher than that of $G^{\prime \prime}$. The different rates led to a crossover of $G^{\prime}$ and $G^{\prime \prime}$, which could be defined as the gel point $\left(G^{\prime}=G^{\prime \prime}\right)$, which was approximately $243 \pm 18 \mathrm{~s}$ for the $\mathrm{TC}_{2} \mathrm{G}$ hydrogel and $1627 \pm 98 \mathrm{~s}$ for the $\mathrm{C}_{2} \mathrm{G}$ hydrogel (Figure $4 \mathrm{a}$ ). Interestingly, both gels had an identical storage modulus at the crossover-point.

Strain sweeps at a constant frequency $(10 \mathrm{rad} / \mathrm{s})$ were performed on the hybrid hydrogels immediately or one week after gelation to determine linear-viscoelastic (LVE) regions (Figure $4 \mathrm{~b}$ ). The storage modulus of the $\mathrm{TC}_{2} \mathrm{G}$ hydrogel doubled from 160 to $320 \mathrm{~Pa}$ at $10 \%$ strain immediately and one week after gelling, respectively. Whilst for the $\mathrm{C}_{2} \mathrm{G}$ hydrogel, G'increased from 130 to $334 \mathrm{~Pa}$ at 10\% strain immediately and one week after gelling, respectively. At the crossover point (flow point), the storage modulus of $\mathrm{TC}_{2} \mathrm{G}$ was $55 \mathrm{~Pa}$ and $40 \mathrm{~Pa}$, immediately after gelling and one week after gelling, respectively. Whereas the storage modulus of $\mathrm{C}_{2} \mathrm{G}$ was $32 \mathrm{~Pa}$ and $89 \mathrm{~Pa}$ after gelling and one week after, respectively (Figure $4 \mathrm{~b}$ ). The flow point is an effective parameter that can be used to show the ability of the hydrogel to maintain its structural stability and prevent particle aggregation [50]. The highest flow point value was obtained for $\mathrm{TC}_{2} \mathrm{G}$ after gelling, which showed the least propensity to flow. Change in $G^{\prime}, G^{\prime \prime}$ and complex viscosity of $\mathrm{TC}_{2} \mathrm{G}$ and $\mathrm{C}_{2} \mathrm{G}$ as a function of frequency at a constant strain of $1 \%$ is shown in Figure $4 \mathrm{c}$. The storage modulus for all of the hydrogels exhibited a plateau in the range 1-100 rad/s, which was indicative of a stable cross-linked network. This $\mathrm{G}^{\prime}$-frequency independent feature was also indicative of a solid-like behaviour and pointed to the strength of the hydrogel, which was highest for $\mathrm{TC}_{2} \mathrm{G}$ amongst all the compositions tested. In the frequency test, $\mathrm{G}^{\prime}$ for $\mathrm{TC}_{2} \mathrm{G}$ and $\mathrm{C}_{2} \mathrm{G}$ immediately after gelling were $141 \mathrm{~Pa}$ and $60 \mathrm{~Pa}$ and were 790 and $202 \mathrm{~Pa}$ one week after gelling, respectively. The loss tangent $(\tan \delta)$, which is the ratio of $G^{\prime \prime}$ to $G^{\prime}$, indicated the overall viscoelasticity of the material and was a measure of the ratio of viscous to elastic conversation of energy during deformation. Tan $\delta$ for $\mathrm{C}_{2} \mathrm{G}$ and $\mathrm{TC}_{2} \mathrm{G}$ were $<0.1$ and $<0.02$, respectively, suggesting both hydrogels were elastic. These observations confirmed that the chitosan-silica hybrid hydrogels were stable and highly crosslinked.

\subsection{Protein Release from Hybrid Hydrogels}

The in vitro release kinetics profile of human insulin, fibronectin and OPG from $\mathrm{TC}_{2} \mathrm{G}$ and $\mathrm{C}_{2} \mathrm{G}$ hydrogels were performed in PBS at $37^{\circ} \mathrm{C}$ and data are shown in Figure 5. Both hydrogels demonstrated that more than $30 \%$ of total proteins were released after the first day, the release was continuous with more than $30 \%$ being released up to 7 days after removing the protein released during the previous day. The total protein loading in $10 \mathrm{mg}$ of hydrogels was $40 \mathrm{ng} / \mathrm{mL}$, and on the first day, the amount of protein released from the hydrogel was $<13 \mathrm{ng} / \mathrm{mL}$. The total protein amount was released within the first week. There was no significant difference between the different proteins or hydrogels analysed. 

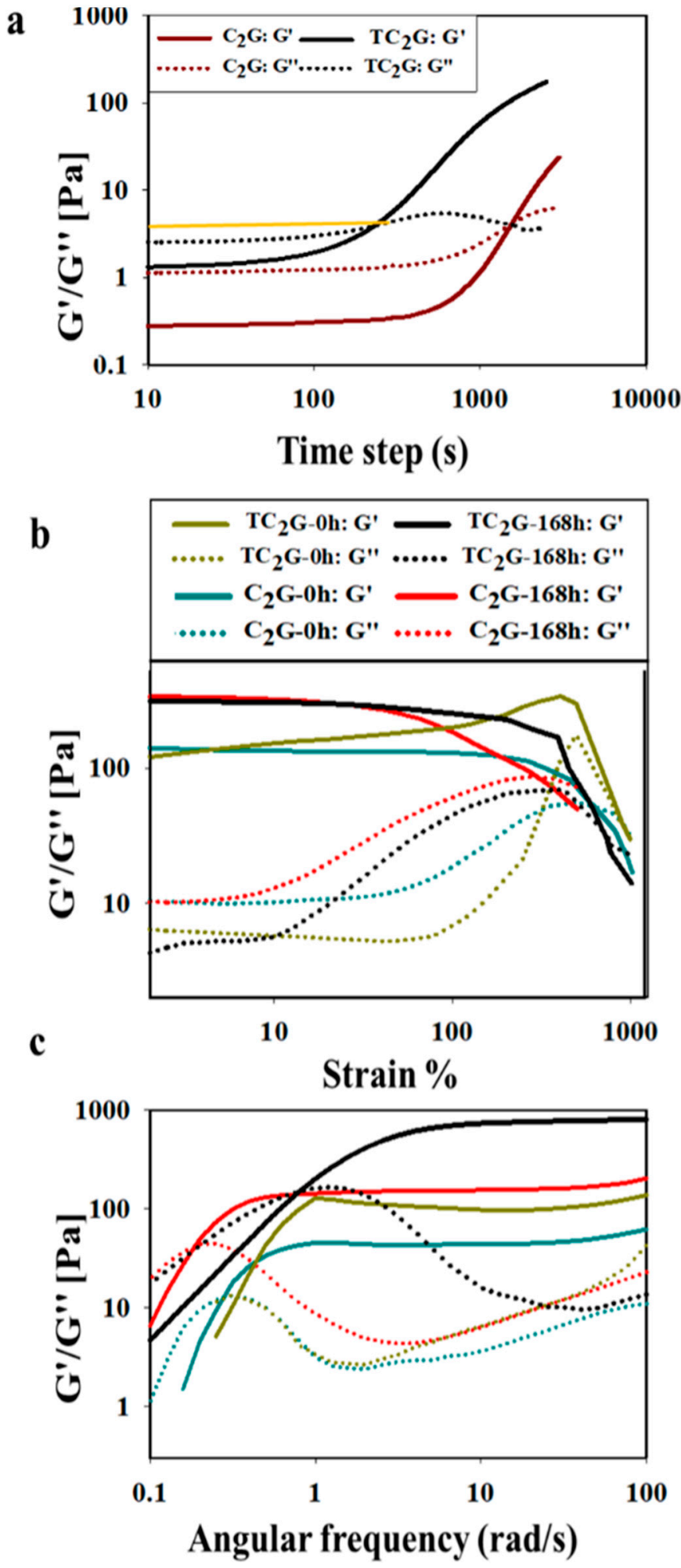

Figure 4. (a) Time dependence of the storage $\left(G^{\prime}\right)$ and loss $\left(G^{\prime \prime}\right)$ moduli for $C_{2} G$ and $T C_{2} G$. The gel point of TC2 $\mathrm{G}$ was around 243s and 1627s for $\mathrm{C}_{2} \mathrm{G}$ and both gels had an identical modulus at the crossover-point. (b) Loss modulus $\left(\mathrm{G}^{\prime}\right)$, storage modulus $\left(\mathrm{G}^{\prime \prime}\right)$ as a function of strain for $\mathrm{TC}_{2} \mathrm{G}$ and $\mathrm{C}_{2} \mathrm{G}$ immediately after gelling and one week after. (c) Loss modulus $\left(\mathrm{G}^{\prime}\right)$, storage modulus $\left(\mathrm{G}^{\prime \prime}\right)$ as a function of frequency for $T C_{2} G$ and $C_{2} G$ immediately after gelling $\left(G^{\prime} / G^{\prime \prime} /\right.$ complex viscosity 1$)$ and one week after gelling. $\mathrm{TC}_{2} \mathrm{G}$ has the highest storage moduli over one week. 


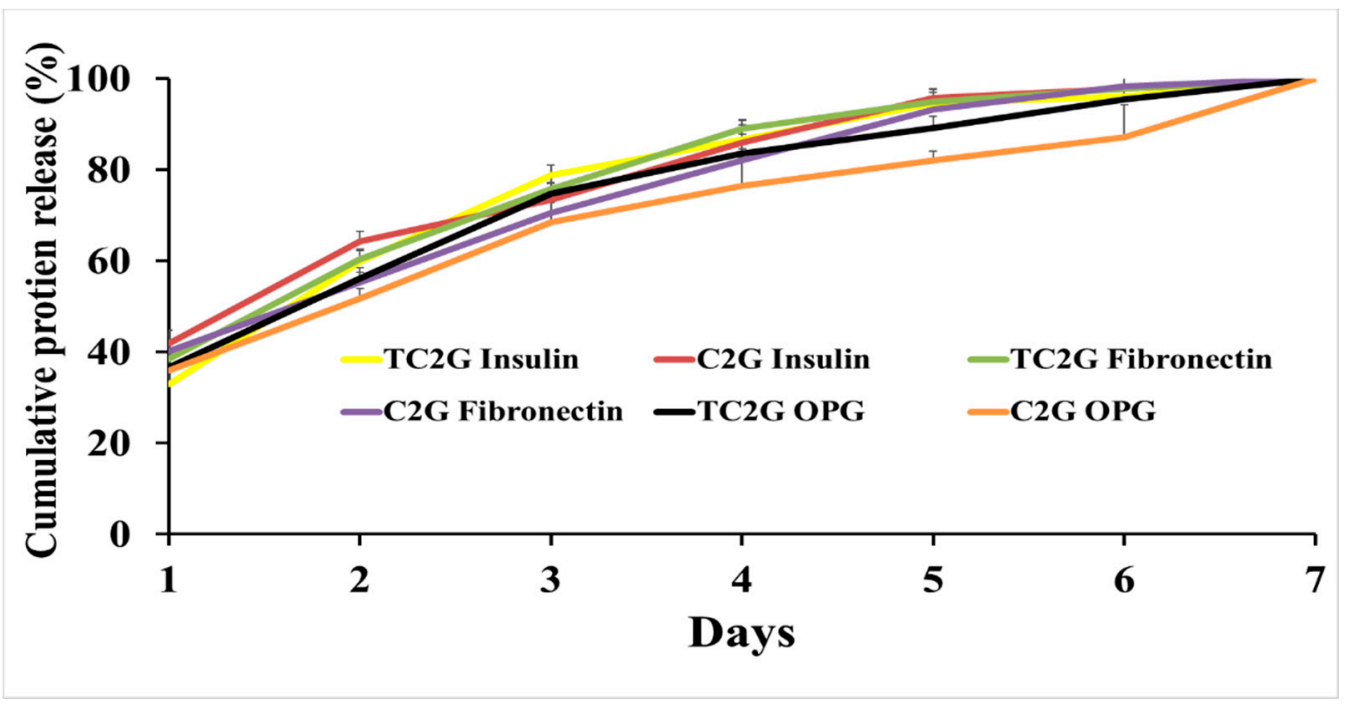

Figure 5. In vitro release of human insulin, fibronectin and OPG from $\mathrm{C}_{2} \mathrm{G}$ and $\mathrm{TC}_{2} \mathrm{G}$ over a 7-day period. The total protein loading in hydrogels was released in the first week. Triplicates for each hydrogel were analysed and means are shown.

\subsection{Assessment of Cell Viability Seeded on/within Hybrid}

The viability of osteoblasts (SaOs-2 cells) treated with media extracts compared with cells seeded on wells with basal media was greater than $80 \%$ over the $72 \mathrm{~h}$ culture period (Figure 6a). When cells were directly seeded on the hydrogels, all hydrogels exhibited limited cytotoxicity as osteoblast viability remained at $<70 \%$ until $72 \mathrm{~h}$ compared with controls (Figure 6b). Osteoblast viability increased gradually with increasing culture time. The viability of cells on thiolated chitosan-silica hybrids reached $\sim 80 \%$ by $168 \mathrm{~h}$. A LIVE/DEAD assay was also used to visualise the distribution of living and dead cells in the hydrogels at different time points for the 3D culture system. Relatively few dead cells were apparent and the number of live cells was much higher at 7 days (Figure 6c). The viability of cells encapsulated within hybrid hydrogels was $\geq 80 \%$ in $\mathrm{TC}_{2} \mathrm{G}$ and $\geq 70 \%$ in $\mathrm{C}_{2} \mathrm{G}$ for culture times up to $168 \mathrm{~h}$ (Figure $6 \mathrm{~d}$ ). There was a significant difference between $\mathrm{TC}_{2} \mathrm{G}$ and $\mathrm{C}_{2} \mathrm{G}$ materials at all-time points $(p<0.05)$. Statistical analysis of data obtained for the different hydrogels on the viability of osteoblasts are summarized in supporting information Table S4.

The morphology of the cells seeded in the hydrogels was assessed using SEM (Figure 7a). SEM images revealed the interaction of cells with the surrounding hydrogel matrix and protruding cell clusters from the hydrogels. Cells appeared attached to the hydrogel surface or encapsulated within the hydrogel. Also, SEM imaging revealed that the hydrogels were amorphous solids lacking pores or ordered structure. Cryo-SEM images show that the morphology of the organic-inorganic hybrid hydrogel after $168 \mathrm{~h}$ of cell culture was represented by a matrix of evenly distributed agglomerated particles. The gels were smooth and non-porous and the globular structures on the sample surface exhibited the formation of a 3D network of $\mathrm{Si}-\mathrm{O}-\mathrm{Si}$ bonds. Cryo-SEM micrographs of the fracture surface of $\mathrm{TC}_{2} \mathrm{G}$ hydrogels showed cells encapsulated in the hydrogel matrix (Figure $7 \mathrm{~b}$ ). 

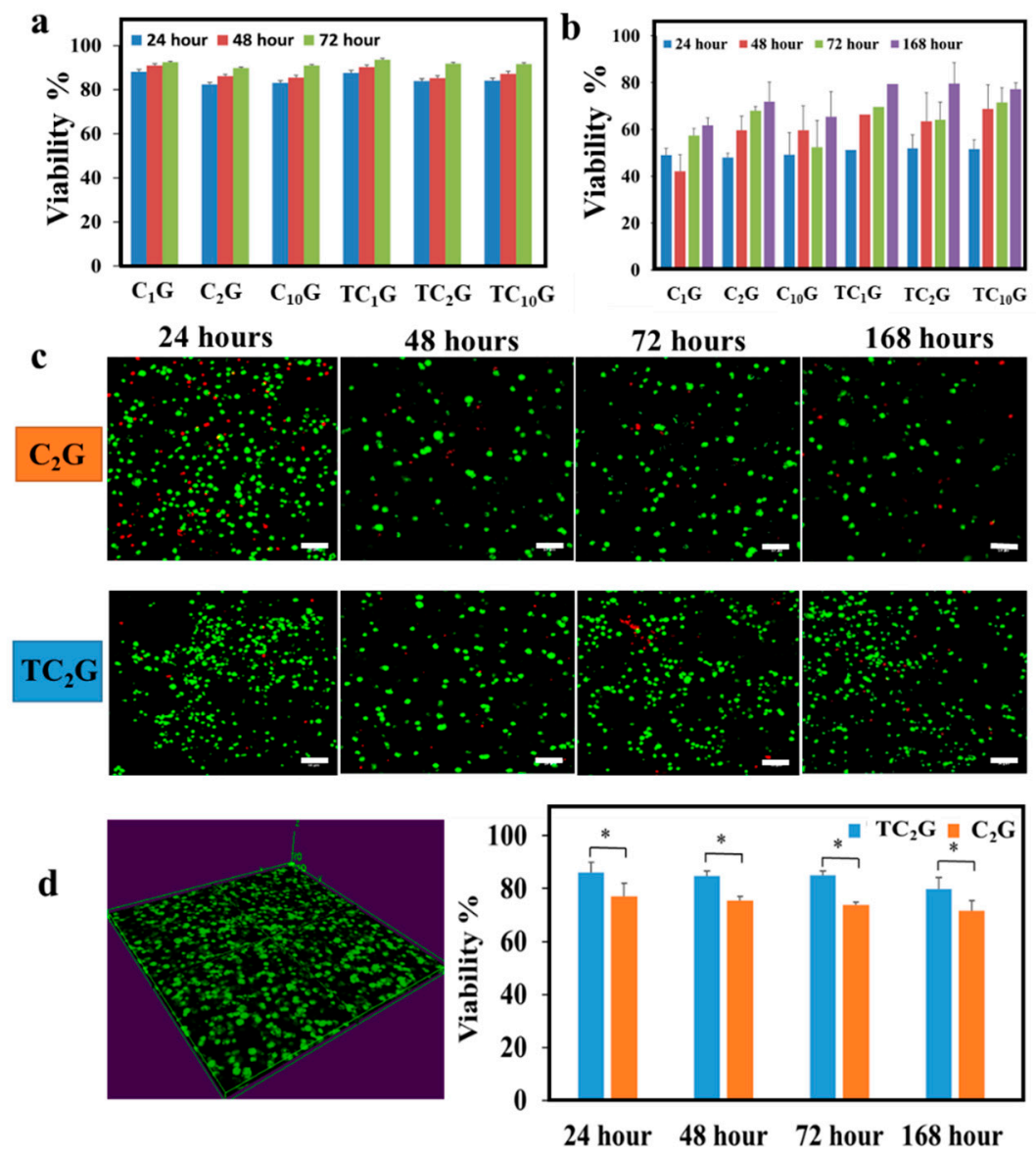

Figure 6. Effect of the different hydrogels on viability of osteoblasts seeded on these surfaces using the direct contact method up to $168 \mathrm{~h} \mathrm{(a)} \mathrm{and} \mathrm{the} \mathrm{indirect} \mathrm{contact} \mathrm{method} \mathrm{up} \mathrm{to} 72 \mathrm{~h}$ (b). (c): Representative confocal laser microscopic images stained using the live/dead assay for osteoblasts encapsulated in $\mathrm{C}_{2} \mathrm{G}$ and $\mathrm{TC}_{2} \mathrm{G}$ for $24,48,72$ and $168 \mathrm{~h}$ (Scale bar is $50 \mu \mathrm{m}$ ). The green colour indicated viable cells and the red colour indicated non-viable cells. (d) image of hybrid hydrogels showing cells were encapsulated and evenly distributed within the hybrid hydrogels. Viability percentages of encapsulated osteoblasts in hydrogels at $24,48,72$ and $168 \mathrm{~h}$. The viability of cells was $\geq 70 \%$ at $168 \mathrm{~h}$. Data are expressed as mean \pm SD $(n=3)$. * denotes significant difference in viability percentage $(p<0.05)$ identified between the two hydrogels.

\subsection{Assessment of Antibacterial Activities of Hybrid Hydrogels}

The result of colony-forming units assay showed that the $C_{2} G$ hydrogels demonstrated antimicrobial activity against $P$. aeruginosa and E. faecalis, with a reduction of up to $2 \log 10 \mathrm{CFU} / \mathrm{mL}$ compared with the control. The $\mathrm{TC}_{2} \mathrm{G}$ hydrogel in comparison only showed a $1 \log 10 \mathrm{CFU} / \mathrm{mL}$ reduction of $E$. faecalis and no reduction for $P$. aeruginosa (Figure 8a). The live/dead assay showed that $\mathrm{TC}_{2} \mathrm{G}$ hydrogels led to $>80 \%$ of bacterial death for both strains after $24 \mathrm{~h}$ incubation, whilst $\mathrm{C}_{2} \mathrm{G}$ led to $70 \%$ death of E. facaelis and $>80 \%$ for P. aeruginosa (Figure $8 \mathrm{~b}$ ). Confocal microscopy images of E. facaelis and $P$. aeruginosa on the hydrogel surfaces showed that the majority of the bacteria were dead on both hybrid hydrogel types, as indicated by the red stain (Figure 8c). The attachment assay showed the number of bacteria on the $\mathrm{C}_{2} \mathrm{G}$ hydrogel surface was significantly higher than on $\mathrm{TC}_{2} \mathrm{G}$, with almost all bacteria appearing dead (Figure $8 \mathrm{~d}$ ). This was supported by scanning electron microscopy images showing bacterial adherence on the $\mathrm{C}_{2} \mathrm{G}$ gel, whilst no bacteria appeared adhered to $\mathrm{TC}_{2} \mathrm{G}$ (Figure 8e). 


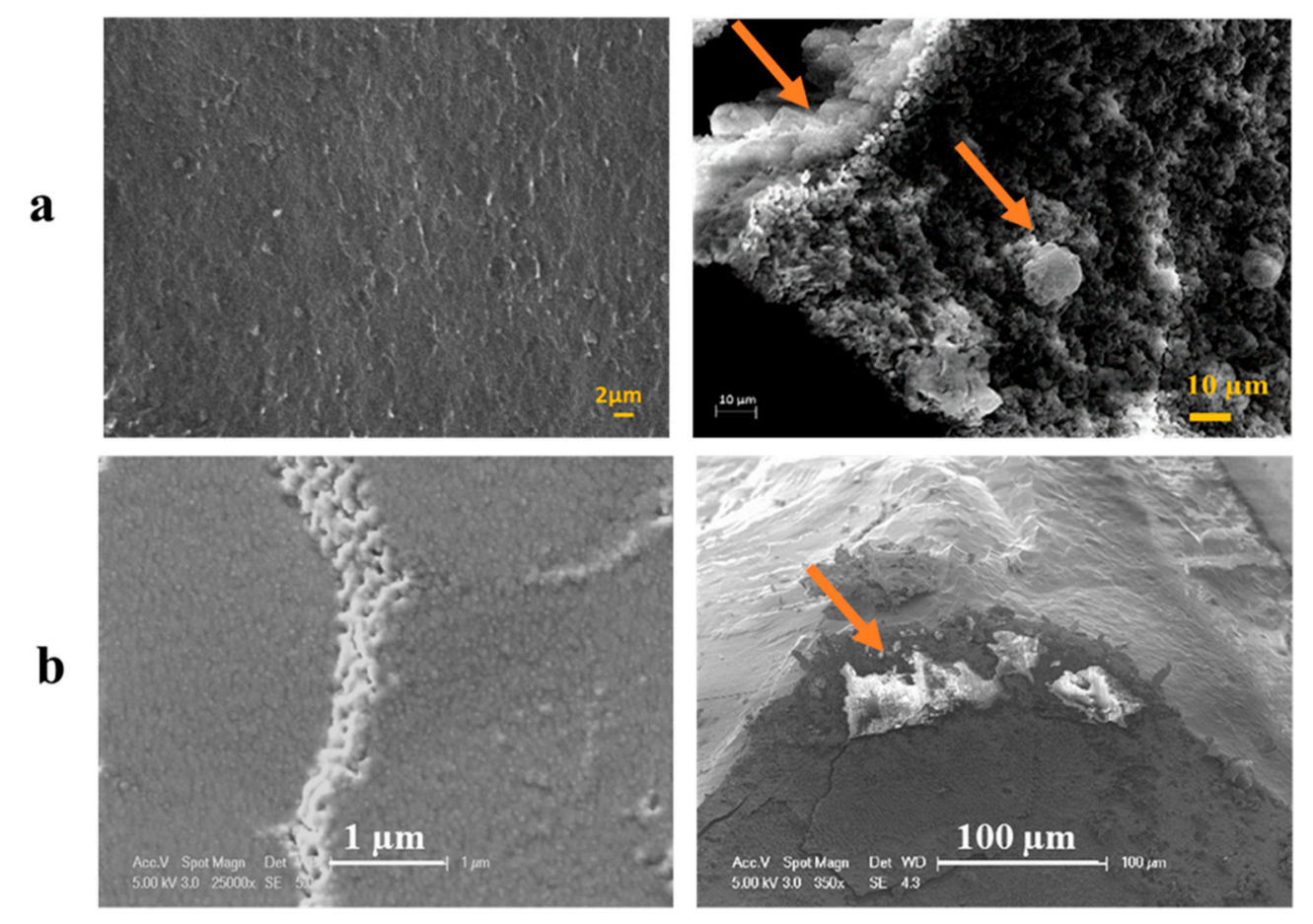

Figure 7. (a) SEM micrographs of $\mathrm{C}_{2} \mathrm{G}$ hydrogels without cells and with cells at $168 \mathrm{~h}$ after encapsulation. (b) Cryo-SEM image of $\mathrm{TC}_{2} \mathrm{G}$ showing the non-porous structure of the hydrogel and osteoblasts inside $\mathrm{TC}_{2} \mathrm{G}$ at $168 \mathrm{~h}$ (Scale bar $=100 \mu \mathrm{m}$ ). The arrows indicate cells in the hydrogel.

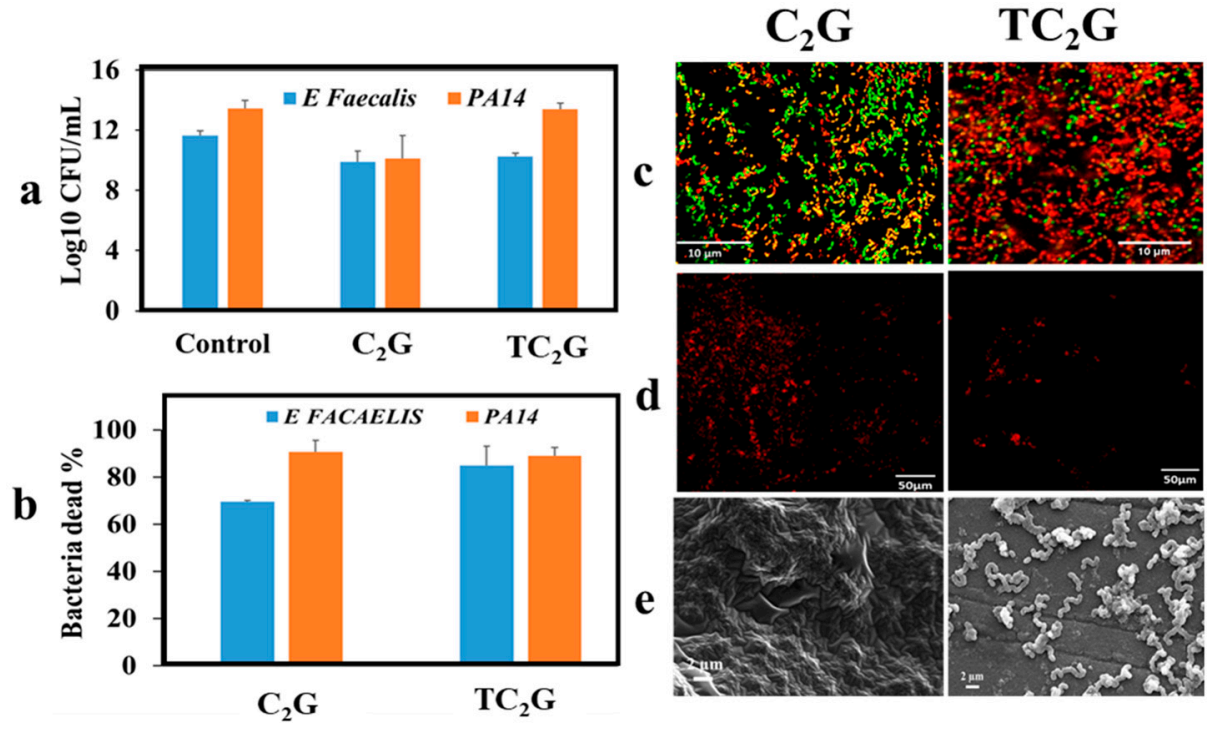

Figure 8. (a) Antimicrobial activity of hydrogels. $\log _{10}$ reduction of bacteria (mean $\log \mathrm{CFU} / \mathrm{mL}$ of $x$ experiments) after $24 \mathrm{~h}$ incubation on hydrogel and CFU plating. The control represented only bacteria without incubation on hydrogel. (b) quantitative data of the effect of hybrid hydrogels on the viability of bacteria stained with LIVE/DEAD ${ }^{\circledR}$ Bacterial Viability Kit showing more $>70 \%$ of bacteria dead after incubation with the hydrogels for $24 \mathrm{~h}$. (c) Representative confocal microscopy images of bacteria on the surface of hydrogels after $24 \mathrm{~h}$ incubation period. Fluorescence images showing live (green) and dead (red) bacteria. (d) Fluorescence images (Live/dead stain) showing bacteria are dead in the hydrogels after $24 \mathrm{~h}$. (e) SEM micrographs of bacteria attached to the surface of $\mathrm{C}_{2} \mathrm{G}$ hydrogels and not attached on the surface $\mathrm{TC}_{2} \mathrm{G}$ hydrogels at $24 \mathrm{~h}$. 


\section{Discussion}

\subsection{Hybrid Formation}

Hydrogels are mainly formed from organic materials and appear to have excellent properties as natural biopolymers for biomedical applications tend to contain the appropriate ligand chemistry. However, the mechanical properties of these hydrogels can be relatively poor and degradation is not predictable. On the other hand, uncontrolled degradation of inorganic hydrogels can hinder stability [51]. Thus, a hybrid hydrogel will give molecularly interpenetrating networks, which are important for maintaining the bioactivity from organic components and mechanical reinforcement from inorganic constituents.

Organic with inorganic crosslinkers such as GPTMS can be employed to overcome uncontrolled degradation. So far, several studies have reported the synthesis of organicinorganic hybrids using chitosan as the organic source [52-56]. Thiolated chitosan offers advantageous features over unmodified chitosan including significantly improved permeation and mucoadhesive properties arising from thiol groups present on side chains. Thiolated chitosan is also able to form a gel in physiological conditions that facilitates controlled drug release and cell delivery [35,57]. In these hybrid materials, GPTMS was used to cross-link thiolated chitosan and chitosan with inorganic silica derived from a novel silica precursor GLMS. The functionalisation of chitosan (C) and thiolated chitosan (TC) with GPTMS was initially assessed. There are several chemical groups on chitosan for functionalisation with the epoxy ring on GPTMS [49], and functionalisation of two of these groups is more likely to occur using the reaction conditions employed here (Figure 1a). One of the mechanisms proposed utilises covalent coupling of the epoxide ring to the primary amine to form a secondary amine [58-60], whilst the other proposed covalent coupling is between the hydroxyl groups of the chitosan via the epoxide ring [61]. Also, during the reaction, the epoxide ring-opening reactions of GPTMS can proceed according to two mechanisms. If the epoxide reacts in basic condition, nucleophiles attack the less substituted carbon while in acidic condition; nucleophiles attack the more substituted carbon to open the epoxide ring and the epoxide ring open to form a diol, (Figure 1a).

A schematic diagram of the silica-organic network in hydrogels is shown in Figure $1 b$. Chemical characterization (FTIR and ${ }^{1} \mathrm{H}$ NMR) confirmed that the hydrogels formed Class II interactions via GPTMS. FTIR spectra of thiolated chitosan prepared in this study did not show any differences compared with unmodified chitosan, this may have been due to the presence of relatively small amounts of thiols. However, the protocol adopted was published previously by Bernkop-Schnürch [62] who showed complete characterisation of the functionalised polymer. Furthermore, functionalised chitosan was soluble in water while unmodified chitosan required an acidic $\mathrm{pH}$ to become soluble. Additionally, the NMR spectrum of thiolated chitosan showed a chemical shift for the H-2 proton suggesting the apparent successful functionalisation of chitosan with thiol groups.

Varghese et al. (2010) hypothesised that the epoxide ring would react with the -OH groups of the chitosan and this may be observed for the CG hybrid due to the protonation of amine in chitosan at acidic $\mathrm{pH}[61,63]$, however, others have conclusively shown that the reactions of amine with the epoxy group on GPTMS occurred at acidic $\mathrm{pH}$ [49]. However, it was likely that a mixture of both reactions occurred in the conditions employed here [64]. The higher $\mathrm{pH}$ of the reaction between thiolated chitosan and GPTMS compared with chitosan and GPTMS would have increased the chances of an epoxied reaction with the amine group in thiolated chitosan (Figure 1a). However, it should be noted that there remained a possibility that the reaction may have occurred through hydrogen bonding between amine, amide or hydroxyl species and epoxide groups or ionic bonding between the positively charged amine groups and negatively charged silanes. In addition, the condensation of the silanol groups on the opposing end of the GPTMS molecules was also observed to occur simultaneously. This highlights the dual reactivity of GPTMS and adds further complexity to characterising its reactivity and efficiency in coupling $[65,66]$. 


\subsection{Degradation Behaviour}

The weight loss of hydrogels showed that the composition of hybrids with a 2:1 organic: inorganic ratio had the slowest degradation rate. Previous studies have reported the organic: inorganic weight ratios to show the greatest influence on degradation behaviour. Increasing the inorganic content resulted in a highly condensed network formed in the hybrid which resulted in decreased degradation [24,67].

To better understand the contributions of hydrolytic dissolution and enzymatic degradation on the breakdown of hydrogels, $\mathrm{TC}_{2} \mathrm{G}$ and $\mathrm{C}_{2} \mathrm{G}$ samples were incubated in PBS with or without lysozyme for 21 days. It has been reported that in the human body, chitosan is mainly degraded by lysozyme which hydrolyses linkages between glucosamineglucosamine, glucosamine- $\mathrm{N}$-acetyl-glucosamine and N-acetyl-glucosamine- $\mathrm{N}$-acetylglucosamine units $[68,69]$. The present study utilised a concentration of lysozyme corresponding with levels present in human serum [70] and was used to mimic the in vivo degradation; results were compared with those in lysozyme-free PBS.

In the degradation solutions, burst release of silica and chitosan from hybrid hydrogels occurred in the first few days and then the release rate continued to decrease up to 21 days, while most of the glycerol species were released in the first week, which was responsible for the majority of the weight loss from the hydrogels. This possibly indicated relatively weak electrostatic interactions between glycerol and chitosan, while the chitosan matrix crosslinked with the silica which was degraded enzymatically by chitosan chain cleavage. The rate of degradation was found to be dependent on the amount of GPTMS or, in other words, the degree of crosslinking [71]. Chitosan is degradable at a relatively slow rate, however, in the presence of lysozyme, the degradation was accelerated. According to a previous study, the incorporation of glycerol in the hydrogel systems which contained acrylic acid, N-vinyl-2-pyrrolidone affected the degradation rate, as more than $40 \%$ glycerol content in the hydrogel caused destruction of the hydrogen bonds between polymer chains, which decreased the cross-linking density of gels [72]. That phenomenon may have explained the rapid degradation of the hydrogels in the present study over the first few days followed by the subsequent slower degradation.

\subsection{Rheological Properties of Hybrid Hydrogels}

Oscillation rheometry was performed to assess kinetics of gel formation, strength and the viscoelastic nature of the hybrid hydrogels. Gelation of the thiolated chitosan hybrid formulations occurred faster compared with chitosan and this agreed with Stefanov et al. [73] who reported that as the degree of chitosan thiolation increased, the gelation time reduced. This was expected as the thiol groups were able to participate in network formation. Both $G^{\prime}$ and $G^{\prime \prime}$ increased rapidly as gelation proceeded; the build-up rate of $\mathrm{G}^{\prime}$ was much higher than that of $\mathrm{G}^{\prime \prime}$. This may have occurred due to the formation of an elastic hydrogel from the crosslinked formation between polyglycerol and chitosan/silica. The transition of the chitosan/silica/glycerol system from a liquid-phase to a solid-phase revealed viscoelastic behaviour and also suggested the formation of a three-dimensional (3D) network [74]. For applications that require hydrogels with reduced gelation times, e.g., for use in the surgical application, $\mathrm{TC}_{2} \mathrm{G}$ potentially provides a useful hybrid hydrogel. Indeed, the advantages of short gelation times avoids excessive drug diffusion in delivery systems or heterogeneous cell distribution within the matrix [75-78]. Of particular interest was that both gels at different time-points exhibited an identical modulus at the crossoverpoint indicating a critical strength above which both gels behaved as solids and the network on these materials could be similar or identical to each other.

The effect of the strain amplitude on the hydrogels showed beyond the linear viscoelastic region (LVR) that the elastic modulus abruptly decreased (Figure $4 \mathrm{~b}$ ) indicating that structural breakdown occurred as a consequence of the large deformations imposed. A constant $G^{\prime}$ with increasing strain corresponds with an elastic gel which when $G^{\prime}$ begins to decrease or exhibit a crossover with $G^{\prime \prime}$ and suggested the gel had become more viscous [79]. $\mathrm{TC}_{2} \mathrm{G}$ showed an increase in $\mathrm{G}^{\prime}$, which represented the elastic component of 
the materials deformation and was correlated with the number of effective intermolecular cross-links formed in the hydrogel network and consequently, the extension of LVR [77]. At high frequency, $G^{\prime}$ was higher than $G^{\prime \prime}$. $G^{\prime}$ indicated a stronger gel network so $T_{2} G$ had improved the strength of hydrogel than $C_{2} G$. At low frequency, $G^{\prime \prime}$ was higher than $\mathrm{G}^{\prime}$ and this property was related to the relaxation time of the molecular chains. At low frequency, relaxation was greater and the chains could relax more slowly, reducing $G^{\prime}$ and $G^{\prime \prime}$ [80]. With time the hybrid hydrogels demonstrated increased storage modulus; this was due to the continued polycondensation of the silica network in the hydrogel often seen during the ageing phase of sol-gel materials. A comparison between the chitosan-based hydrogels ( $2.5 \mathrm{wt} \%$ ) produced here and gelatin methacryloyl hydrogels (GelMA) (5 wt $\%$ ) reported in the literature [81] was made. The $\mathrm{G}^{\prime}$ in a frequency sweep test was reported to be $275 \pm 10 \mathrm{~Pa}$ [81] whilst the Class II silica-chitosan hybrid hydrogels, in particular, $\mathrm{TC}_{2} \mathrm{G}$ had higher $\mathrm{G}^{\prime}$ (790 Pa) while $\mathrm{C}_{2} \mathrm{G}$ was relatively similar to GelMA (202 Pa).

Tan $\delta$ of $\mathrm{TC}_{2} \mathrm{G}$ was higher than $\mathrm{C}_{2} \mathrm{G}$, therefore the structures of $\mathrm{TC}_{2} \mathrm{G}$ were considered to be strong. Due to these observations, these hydrogels were considered as stable and strongly crosslinked gels [82]. This stiffening and more solid-like behaviour was caused by the inability of longer polymer chains to rearrange in the given time scale. Thus, $\mathrm{TC}_{2} \mathrm{G}$ had a more "solid-like" structure and offered the potential for tailoring mechanical performance to meet the demands of specific applications.

\subsection{Hybrid Hydrogels As a Drug Delivery System}

To assess the ability of hybrid hydrogel to be used as a drug delivery system, a range of different molecular weight proteins including human OPG (20 kDa), fibronectin (220 kDa), and insulin $(5.7 \mathrm{kDa})$ were selected and loaded into the hydrogels. In general, protein loading efficiencies decreased as protein molecular weight increased. However, high loading efficiencies for different molecular weights in $\mathrm{TC}_{2} \mathrm{G}$ and $\mathrm{C}_{2} \mathrm{G}$ were identified as the total loading protein was released in one week. This implied that molecular weight was not the only factor influencing protein loading and release as no significant difference between different molecular weight proteins released from hydrogels was observed. Protein charge is also identified as a major factor in protein loading efficiency [83]. The amino groups on the chitosan can bind with hydrogen ions to be protonized and consequently exhibit positive charges. At $\mathrm{pH} 6.5$, positively charged chitosan was loaded with negatively charged proteins through electrostatic interactions. Various protein release profiles could be altered by the electrostatic interactions between chitosan and the proteins [84].

Insulin, fibronectin and OPG support a negative net charge at neutral $\mathrm{pH}$ values $[85,86]$ enabling loading in chitosan particles more efficiently and providing mucoadhesive properties for adsorption of proteins. The hydrogel developed in this study contained a relatively large amount of water and had less polymeric mass, which was favourable for highconcentration drug loading. However, this can lead to rapid drug release as a result of high mobility of drug molecules in solution within the hydrogel. Our hydrogels were prepared in solutions with a physiological $\mathrm{pH}$, allowing the safe incorporation of bioactive molecules for a broad range of medical applications, particularly for in vivo drug release.

\subsection{Cell-Material Interactions}

The effect of different ratios of organic-inorganic hybrids on the viability of cells has not previously been examined. Our data showed that there was no significant difference between different organic-inorganic ratios on the viability of osteoblasts. The osteoblast viability after encapsulation of cells in the hydrogels was similar at different time-points and the hydrogels did not appear to exert a significant harmful effect on cell viability. Based on previous studies, cytotoxicity responses were classed as slightly cytotoxic when the percentage cell viability was $60-90 \%[87,88]$. Interestingly, cell viability increased with time in direct and indirect assays and was not affected by the hydrogel after 7 days. These observations indicated that the hybrid hydrogel was not toxic and supported cell growth. Cell viability in TCG hydrogels was higher than in $C_{2} G$ hydrogels which may 
be explained by the water-soluble chitosan (thiolated chitosan) not requiring an acidic vehicle for solubilisation whilst chitosan required an acidic environment, which could have been detrimental to cells. Furthermore, incorporation of glycerol into the hydrogel may help to deliver therapeutic agents that enhance cell growth and improve wound healing capabilities of these hydrogels. Indeed, some studies have shown that glycerol incorporation can increase the release of therapeutic agents in the early stages of the release profile by enhancing the formation of water channels $[89,90]$.

In addition, SEM/Cryo-SEM images showed cell attachment and growth on the surface and within the hydrogels. SEM imaging revealed that the hydrogels were soft solids lacking macropores and as previous studies have reported this allowed for dynamic rearrangement of the hydrogel networks to facilitate cell motility [91]. Hybrid hydrogel matrices are water swollen networks of organic and inorganic phases. Therefore, they would exhibit "pores" at the nano to molecular scale. Hydrogel matrices can be either non-porous (having only relatively small pores that are typically in the range of tens of $\mathrm{nm}$ for the gel network), or contain macroscopic pores that are typically in the range of $10-500 \mu \mathrm{m}$. Dual nano- and macro-porosity is essential for controlled growth of a tissue and drug delivery [92-94].

\subsection{Antibacterial Activities of Hybrid Hydrogels}

The antibacterial activities of these hydrogels were tested using P. aeruginosa and E. faecalis which are the most common bacteria responsible for prosthesis-related infections [95]. The positive charge of chitosan could facilitate electrostatic cross-linking with bacterial membranes, thus enhancing antibacterial activity [96]. Both $C_{2} G$ and $\mathrm{TC}_{2} \mathrm{G}$ inhibited growth of E. faecalis efficiently; moreover, $\mathrm{C}_{2} \mathrm{G}$ also inhibited P. aeruginosa. Additionally, $\mathrm{TC}_{2} \mathrm{G}$ showed an anti-adherent effect which may be explained by a combination of factors, including the reduction of free available amine groups of chitosan, which have previously been related to the adherence of bacteria observed on $\mathrm{C}_{2} \mathrm{G}$ and the increase of surface hydrophilicity, which can decrease bacterial adhesion directly or indirectly through decreased protein adsorption [97]. Therefore, it appears that using thiolated chitosan provides surface characteristics that are interesting for inhibiting bacterial adhesion. Nevertheless, it is not clear if the exposed thiol group had any direct contribution in preventing specific adhesion (e.g., degrading relevant disulfide bridges of bacterial adhesins), or if the overall mechanism was purely non-specific anti-adhesive [97].

\subsection{Limitations of Study and Future Works}

In this study, the effect of hydrogels on viability and mineralisation of osteoblasts in long-term cell culture was not evaluated. This requires further investigation in future studies using cells to study the effect of hydrogels on the differentiation, proliferation and mineralisation capability of cells.

\section{Materials and Methods}

\subsection{Materials}

Low molecular weight chitosan (75-85\% deacetylated), 2-iminothiolane hydrochloride and an organosilane (3-glycidyloxypropyl) trimethoxy silane (GPTMS) were purchased from Merck (Darmstadt, Germany) and used in polymer functionalisation. Human recombinant osteoprotegerin (OPG, PEPROTECH, $1 \mathrm{mg}$, East Windsor, NJ, USA), human recombinant insulin (Sigma-Aldrich, Gillingham, UK), human fibronectin (Sigma-Aldrich, Gillingham, UK) were used for protein release assay. ELISA kits for human insulin, fibronectin and OPG were purchased from R\&D Systems (Minneapolis, MN, USA). The human osteosarcoma cell line, SaOs-2 (ATCC HTB-85, Manassas, VA, USA), cell culture medium McCoys (Sigma-Aldrich, Gillingham, UK) supplemented with 10\% (v/v) foetal calf serum (Biosera, Nuaillé, France), $0.297 \mathrm{~g}$ L-glutamine $/ 500 \mathrm{~mL}$ bottle of media (Sigma-Aldrich, Gillingham, UK), 1\% penicillin-streptomycin (PS; $100 \mathrm{IUmL}^{-1}$ penicillin, $0.1 \mathrm{mg} \mathrm{mL}^{-1}$ streptomycin (Sigma-Aldrich, UK) were used for cell culture. Resazurin 
sodium salt $(0.3 \mathrm{mg} / \mathrm{mL})$ (Sigma-Aldrich, Gillingham, UK) was used for the Alamar Blue assay and the live/dead two-colour fluorescence assay was purchased from ThermoFisher (Waltham, MA, USA).

\subsection{Synthesis of Hydrogels}

\subsubsection{Functionalisation of Chitosan}

Thiolated chitosan (TC) was synthesised as previously described [62]. In brief, $5 \mathrm{~g}$ of low molecular weight chitosan (C) was dissolved in $500 \mathrm{~mL}$ of $1 \%$ acetic acid, the $\mathrm{pH}$ was adjusted to 6 with $5 \mathrm{M} \mathrm{NaOH}$ and reacted with $0.1 \mathrm{mg} / \mathrm{mL}$ of 2-iminothiolane $\mathrm{HCl}$ (50 mg) for $24 \mathrm{~h}$ with continuous stirring at room temperature. The solution was then dialysed against dilute $\mathrm{HCl}$ (twice against $5 \mathrm{mM} \mathrm{HCl}$ containing $1 \% \mathrm{NaCl}$ followed by $5 \mathrm{mM} \mathrm{HCl}$ and finally against $0.4 \mathrm{mM} \mathrm{HCl}$ ). Dialysed TC was freeze-dried at $-60{ }^{\circ} \mathrm{C}$ and 0.4 mbar (Edwards K4 Modulyo Freeze Dryer) and stored at $4{ }^{\circ} \mathrm{C}$ until use. Thiolated chitosan was further functionalised with GPTMS before hydrogels were synthesised. Thiolated chitosan (17 mg/mL) was initially dissolved in deionized water and GPTMS was pipetted in at chitosan monomer to GPTMS molar ratio of 4:1 and stirred for $24 \mathrm{~h}$ at room temperature $[22,49]$. Low molecular weight chitosan was functionalised with GPTMS using the same approach, however, the chitosan was dissolved in $1 \%$ acetic acid and after reaction with GPTMS, the $\mathrm{pH}$ was adjusted to 6.5 with $0.5 \mathrm{M} \mathrm{NaOH}$.

\subsubsection{Synthesis of Glycerol-Modified Silane (GLMS) Precursors}

Tetraethyl orthosilicate (TEOS; Merck, Germany) was transesterified with dry glycerol (Merck, Germany) with 1:4 (TEOS: glycerol) ratio at $140{ }^{\circ} \mathrm{C}$ in an argon atmosphere as previous described [98-100]. The reaction was performed until distillation of ethanol stopped. GLMS was stored in a dry atmosphere at room temperature to prevent reaction with moisture.

\subsubsection{Hydrogel Formation}

GLMS was dissolved in deionized water or cell culture media and added to functionalised chitosan solution in different organic-inorganic weight ratios $(1: 1,2: 1$ and 10:1) to prepare thiolated chitosan-ilica hybrid or chitosan-silica hybrid solutions. The hybrid solutions were allowed to gel under room temperature to form the hydrogels (Thiolated-silica hydrogels: $\mathrm{TC}_{1} \mathrm{G}, \mathrm{TC}_{2} \mathrm{G}$ and $\mathrm{TC}_{10} \mathrm{G}$ or chitosan-silica hydrogels: $\mathrm{C}_{1} \mathrm{G}, \mathrm{C}_{2} \mathrm{G}, \mathrm{C}_{10} \mathrm{G}$ ) with 3 , 2.5 and $2 \mathrm{wt} \%$ respectively. The amount of chitosan/thiolated chitosan, GPTMS and GLMS used to prepare $1 \mathrm{~mL}$ of hybrid hydrogels are given in Table 1.

Table 1. The amounts of chitosan/thiolated chitosan, GPTMS and GLMS used in a $1 \mathrm{~mL}$ hydrogel.

\begin{tabular}{cccc}
\hline Hydrogel & Chitosan/Thiolated Chitosan (mg) & GPTMS (mg) & GLMS (mg) \\
\hline $\mathrm{TC}_{1} \mathrm{G} / \mathrm{C}_{1} \mathrm{G}$ & 17 & 6.25 & 100 \\
$\mathrm{TC}_{2} \mathrm{G} / \mathrm{C}_{2} \mathrm{G}$ & 17 & 6.25 & 50 \\
$\mathrm{TC}_{10} \mathrm{G} / \mathrm{C}_{10} \mathrm{G}$ & 17 & 6.25 & 10 \\
\hline
\end{tabular}

\subsection{Physio-Chemical Characterisation of Hydrogels}

4.3.1. Chemical Characterization of Functionalised Polymer and Hydrogels by FTIR and $1 \mathrm{H}$ NMR

The chemical structure of starting materials, functionalised polymers and hydrogels were determined using FTIR in reflection mode (ThermoFisher (Waltham, MA, USA), Nicolet iN10 MX, USA) and 1H NMR (Bruker, AVIII300, USA). Hydrogels were air dried and the FTIR spectra recorded from $400-4000 \mathrm{~cm}^{-1}$, at a resolution of $8 \mathrm{~cm}^{-1}$ and three scans were performed [101]. 1H NMR measurements were performed in $\mathrm{D}_{2} \mathrm{O}$ solution by dissolving $11 \mathrm{mg}$ chitosan in $650 \mu \mathrm{L} \mathrm{D}_{2} \mathrm{O}$ and $6.5 \mu \mathrm{L}$ acetic acid and thiolated chitosan in $650 \mu \mathrm{L} \mathrm{D} \mathrm{D}_{2} \mathrm{O}$. GPTMS was added dropwise to the solutions to produce a chitosan monomer to $6 \mathrm{mg} / \mathrm{mL}$ GPTMS ratio of 4:1 and reacted for $24 \mathrm{~h}$ at room temperature before performing 
1H NMR measurements. Unreacted starting materials including acetic acid, GPTMS, chitosan in acetic acid and thiolated chitosan dissolved in $\mathrm{D}_{2} \mathrm{O}$ were also analysed. Mnova V.14 software was used to analyse NMR spectra.

\subsubsection{Rheological Behaviour of the Hydrogels}

Rheological studies of the hydrogels were performed using a parallel-plate geometry (40-mm diameter, 1-1.4 mm gap) oscillation rheometer (TA Instruments AR G2, Waters, Milford, MA, USA). The temperature of the plates was fixed at $37^{\circ} \mathrm{C}$ using a Peltier-cooled stage. For time-dependent behaviour of hydrogels, the temperature of the Peltier-plate was maintained at $25{ }^{\circ} \mathrm{C}$ (room temperature) to mimic gelling conditions of hydrogels prepared in this study. Strain sweep measurements from 0.1 to $1000 \%$ at a constant frequency $10 \mathrm{rad} / \mathrm{s}$ were performed to determine the strain amplitude in the linear viscoelastic region (LVE). Frequency sweep studies in the LVE region (0.1 to $100 \mathrm{rad} / \mathrm{s}$ at a constant deformation of $1 \%$ strain) were performed to determine the storage $\left(G^{\prime}\right)$ and loss modulus $\left(G^{\prime \prime}\right)$. An oscillation time sweep was performed to measure and record the evolution of storage and loss modulus ( $\mathrm{G}^{\prime}$ and $\mathrm{G}^{\prime \prime}$, respectively) over a fixed time period, at an angular frequency of $10 \mathrm{rad} / \mathrm{s}$ and at a constant strain of 1\%. TRIOS software (TA, version 4.5.1) was employed to analyse the results of rheological tests.

\subsubsection{In Vitro Degradation of the Hydrogel}

The degradation behaviour of the hydrogels was evaluated by measuring wet weight of the hydrogels (weight of the water-absorbed gel after the excessive fluid is removed from the gel) over time in phosphate buffered saline (PBS, pH 7.4). Hydrogels (10 mg) were placed in polypropylene conical tubes (Cole-Parmer Instrument Company LTD, Eaton Socon, UK), each containing either $5 \mathrm{~mL}$ PBS or $5 \mathrm{~mL}$ PBS containing $1.5 \mathrm{mg} / \mathrm{mL}$ lysozyme. The PBS solutions were replaced with fresh solutions daily. This ensured active lysozyme was present in the media [70,87]. The hydrogel sample and solution were sealed and maintained at $37^{\circ} \mathrm{C}$ with mild agitation $(50 \mathrm{rpm})$ for the duration of the study. Chitosanfree inorganic hydrogels (GLMS hydrogel) $(10 \mathrm{mg})$ prepared by dissolving $0.1 \mathrm{~g}$ GLMS in $1 \mathrm{~mL}$ water at $10 \mathrm{wt} \%$ were used for comparison. Inductively coupled plasma atomic emission spectroscopy (ICP-AES, PerkinElmer, Waltham, MA, USA) was used to obtain the soluble silica release profiles in PBS solution and high-performance liquid chromatography (HPLC, Shimadzu, Wolverton, UK) was used for the quantification of glycerol and glucose in degradation solutions. Experiments were performed in triplicates [102,103].

\subsection{Protein Release from Hybrid Hydrogels}

Hydrogels containing OPG, insulin and fibronectin were also prepared by dissolving $17 \mu \mathrm{g} / \mathrm{mL}$ of protein with GLMS in deionized water to prepare the hydrogel as described previously. OPG concentration was selected based on previous in vitro and in vivo studies $[87,104,105]$. Insulin and fibronectin concentrations were also kept at $17 \mu \mathrm{g} / \mathrm{mL}$ to ensure consistency. Hybrid hydrogels $(10 \mathrm{mg})$ containing insulin, fibronectin and OPG were placed in tubes with $5 \mathrm{~mL}$ of PBS ( $\mathrm{pH} 7.4$ ). Samples were agitated at 40-50 horizontal strokes per minute at $37^{\circ} \mathrm{C}$, the supernatant was collected and replaced with fresh PBS solution at a range of time intervals from 1-7 days. The samples were centrifuged and filtered and the protein release from the gel was analysed by using ELISA for human insulin, fibronectin and OPG following manufacturer's instructions. Experiments were performed in triplicate and the means calculated. The amount of protein added into $10 \mathrm{mg}$ of hydrogel was $40 \mathrm{mg}$, consequently the percentage of protein released from the hydrogel was calculated by dividing the amount of protein released in a specific time by the total protein. 


\subsection{Assessment of Cell-Material Interactions}

\subsubsection{Culture of Osteoblasts (SaOs-2) with Hydrogels}

The cytotoxicity of hydrogels was evaluated by both direct and indirect contact methods using SaOs-2 cells which is a cell line derived from the primary human osteosarcoma. The reagents used to prepare the hydrogels were sterilized using $254 \mathrm{~nm}$ UV light (UV Steriliser Cabinet: Adexa, Hamburg, Germany) for $1 \mathrm{~h}$. The solutions were cast into culture 24 wellplates or petri dishes (Ibidi, Gräfelfing, Germany) and gelled under aseptic conditions in a class II biological safety cabinet (Monmouth Scientific, Bridgwater, UK). Cells were cultured at $37^{\circ} \mathrm{C}$ in a humidified atmosphere of $5 \% \mathrm{CO}_{2}$ in air, in McCoys media. The medium was supplemented with $10 \%$ foetal bovine serum (FBS) with $1 \%$ antibiotics (penicillin-streptomycin) and incubated in $5 \% \mathrm{CO}_{2}$ at $37^{\circ} \mathrm{C}$. All assays were performed in triplicate.

\subsubsection{Indirect Contact Method}

The hydrogels were incubated with McCoys media for $24 \mathrm{~h}$ in $0.2 \mathrm{~g} / \mathrm{mL}$ hydrogel sample to media ratio according to international standard number ISO 10993-12 [106]. Cells were cultured at a density of $2 \times 10^{4}$ cells per well in a 48 -well culture plate for 24,48 and $72 \mathrm{~h}$ in media extracted from hydrogels. Cells cultured in extract-free McCoys media were used as controls. Subsequently, the medium was gently aspirated from the culture wells and replaced with 10\% AlamarBlue reagent to determine cell viability. In the Alamar Blue Reagent assay, the growing cells resulted in a chemical reduction of the Alamar Blue dye from blue to red which can be detected using a fluorescence absorbance detector. Cultures were incubated with the AlamarBlue reagent for $5 \mathrm{~h}$ in culture conditions and $100 \mu \mathrm{L}$ media were collected in a 96-well plate for detection of absorbance at excitation of $570 \mathrm{~nm}$ and emission $600 \mathrm{~nm}$ using a microplate reader (Spark 20M Multimode, Tecan, Männedorf, Switzerland) [107].

\subsubsection{Direct Contact Method}

Hydrogels were prepared following method described in Section 4.5.1 and osteoblasts (SaOs-2) were seeded at a density of $2 \times 10^{4}$ cells per well on the surface of the hydrogels in a 48-well culture plate. Cells seeded on the hydrogel-free 48 -well plate were used as control. After 24, 48, 72 and 168 h, cell viability was determined using the AlamarBlue assay following the method described in Section 4.5.2.

\subsubsection{Live/Dead Assessment of Cell Encapsulated or Seeded on Hydrogels}

The hybrid hydrogel was prepared as previously described in Section 4.2 .3 by mixing GLMS dissolved in deionized water and then adding the functionalised chitosan solution. SaOs- 2 cells were then added to the solution by mixing $100 \mu \mathrm{L}$ of the SaOs- 2 suspension with $900 \mu \mathrm{L}$ of solution to achieve a cell density of 1 -million cells $/ \mathrm{mL}$. From this $200 \mu \mathrm{L}$ of the mixture was pipetted into $35 \mathrm{~mm}$ petri dishes to cover a $21 \mathrm{~mm}$ area with $1 \mathrm{~mm}$ height. A fluorescence assay (LIVE/DEAD) was employed to determine the cell viability in hydrogels at $24,48,72$ and $168 \mathrm{~h}$ of culture. The LIVE/DEAD assay kit contains two fluorescence dyes, calcein-AM, which stains the live cells, and ethidium homodimer-1 which stains the dead cells. Hydrogels were washed in PBS prior to staining. 100-150 $\mu \mathrm{L}$ of the combined LIVE/DEAD assay reagent was added to the surface of the hydrogel. The hydrogels containing the staining agent were allowed to rest for $45 \mathrm{~min}$ in the dark. A Zeiss LSM 700 confocal microscope (Zeiss, Jena, Germany) was used for image acquisition and ImageJ software was used for analysis [108]. Cell viability was calculated as the number of Live cells (green)/number of total cells and expressed as a percentage.

\subsubsection{Scanning Electron Microscopy (SEM) of Hydrogels Containing Cells}

The hydrogels containing cells were imaged at $168 \mathrm{~h}$ after encapsulation using conventional SEM and Cryo-SEM. For SEM, cell encapsulated hydrogels were washed in PBS and fixed in $2.5 \%$ glutaraldehyde in cacodylate buffer for $30 \mathrm{~min}$. Gels were dehydrated 
through a graded series of ethanol from $20 \%, 70 \%, 90 \%$, twice in $95 \%$, and twice in $100 \%$ for 10 min each. Finally, samples were placed in 50:50 in ethanol and 100\% hexamethyldisilizane and allowed to evaporate overnight in a fume cupboard. Once dry, samples were gold sputter coated at $20 \mathrm{~mA}$ for $3 \mathrm{~min}$, to produce a $\sim 20 \mathrm{~nm}$ thick coating using an EM-Tec sputter coater (Emitech K550X, Quorum Technologies, Lewes, UK). Samples were then imaged with a Zeiss EVO/MA10 scanning electron microscope (Zeiss, USA) using an accelerating voltage of $10 \mathrm{kV}$ [109]. Wet hydrogels were imaged using Cryo-SEM. Hydrogels were frozen by plunging into liquid nitrogen and freeze-fractured in the cryo-preparation chamber and cryo-SEM micrographs were obtained using an XL30 FEG ESEM with an accelerating voltage of $5 \mathrm{kV}$ [110].

\subsection{Antibacterial Effects of Hydrogels}

The hydrogels were assessed for their in vitro antibacterial activity against two clinical species of bacteria, including the Gram-positive Enterococcus faecalis (E. faecalis) (ATCC 29212) and the Gram-negative Pseudomonas aeruginosa (PA14). Colony-forming units, adherence assay, and live/dead assay were used to evaluate the antimicrobial properties (Figure S2).

\subsubsection{Colony-Forming Units}

Two representative, clinically relevant bacterial species were used in this study. A single colony grown on Tryptic Soy Agar was inoculated in $10 \mathrm{~mL}$ of Tryptic soy broth (TSB) (Oxoid, Basingstoke, UK) and left to grow over-night at $37^{\circ} \mathrm{C}$ in a shaking incubator (NB-205, N-Biotek, Wonmi-gu, Korea). After 24 h, $100 \mu \mathrm{L}$ of bacteria was diluted in $900 \mu \mathrm{L}$ TSB and the optical density (OD) was read using a 7315 Spectrometer (Jenway, Stone, UK). The over-night cultures were diluted to an optical density of (0.1) and TSB without bacteria was used as standard. $1 \mathrm{~mL}$ of the diluted cultures was added on top of a hydrogel prepared in a 24-well plate and then incubated at $37^{\circ} \mathrm{C}$ for $24 \mathrm{~h}$. After the exposure of the bacteria to the samples, the quantification of viable bacteria in broth was performed using the Miles and Misra Method. Plates were incubated at $37^{\circ} \mathrm{C}$ for $24 \mathrm{~h}$ (Heracell 150i, ThermoFisher, Waltham, MA, USA), and then the numbers of colonies were counted. These results were compared with the number of colony forming units of the untreated control group, which had not been exposed to the hydrogel samples.

\subsubsection{Adherence Assay}

The hydride hydrogels were prepared on 24 well plates. $1 \mathrm{~mL}$ of the overnight bacterial suspension was cultured on the hydrogels ( 0.1 OD) at $37^{\circ} \mathrm{C}$ in a shaking incubator. After $24 \mathrm{~h}$, hydrogels with attached bacteria were removed from the well and washed with PBS to remove loosely adhered bacteria. To observe the bacteria on the hydrogel, live/dead staining and SEM imaging were performed.

\subsubsection{Live/Dead Viability Assay}

A LIVE/DEAD assay was employed to determine the live/dead percentage of bacteria seeded on hydrogels after $24 \mathrm{~h} .3 \mu \mathrm{L}$ of $\mathrm{SYTO}^{\circledR} 9$ stain and $3 \mu \mathrm{L}$ of propidium iodide stain were mixed in $1 \mathrm{~mL}$ of sterilized PBS. $200 \mu \mathrm{L}$ of staining solution was added to the surface of the hydrogel. The hydrogels containing the staining agent were stained for $30 \mathrm{~min}$ in the dark. Zeiss LSM 700 confocal microscope was used for image acquisition and ImageJ software was used for analysis. The percentage of dead bacteria was calculated (number of red stained cells $/$ number of total cells) $\times 100 \%$.

\subsection{Statistical Analysis}

Statistical analysis was performed using parametric One-Way ANOVAs for comparison between the mean values of different groups. The viability percentage of osteoblasts were analysed using independent-sample $t$-tests. 


\section{Conclusions}

The hydrogels demonstrated specific degradation and mechanical properties that supported the growth of cells, which may be used for specific applications such as tissue engineering. The hybrid hydrogels exhibited high protein loading efficiencies and delivered different molecular weight proteins over a week, which indicated a potential use as delivery systems for a range of different molecular weight proteins/molecules. The hydrogels showed no significant cytotoxic effects during material-cell contact indicating the hydrogel could be used to support the growth of cells. Our hydrogels demonstrated antimicrobial activity against $P$. aeruginosa and $E$. faecalis leading to a potential reduction in medical application related infections. It is suggested that these newly developed $T_{2} G$ and $\mathrm{C}_{2} \mathrm{G}$ hydrogels have both inorganic and organic components that could provide inherent bioactivity due to the exposure of both inorganic and organic components to host tissue/cells. In conclusion, it appears that the TCG2/CG2 hybrid hydrogels show potential for the delivery of cells and therefore for possible use in bone tissue engineering, drug and cell delivery systems.

Supplementary Materials: The following are available online at https:/ / www.mdpi.com/article/10 $.3390 /$ ijms222212267/s1.

Author Contributions: Conceptualization, S.N.J., P.R.C., R.M.S. and G.P.; methodology, S.N.J., P.R.C., R.M.S., S.A.K. and G.P.; validation, S.N.J., P.R.C., R.M.S., S.A.K. and G.P.; formal analysis, S.N.J.; investigation, S.N.J.; writing—original draft preparation, S.N.J.; writing-review and editing, P.R.C., R.M.S., S.A.K. and G.P.; supervision, P.R.C., R.M.S., S.A.K. and G.P. All authors have read and agreed to the published version of the manuscript.

Funding: GP would like to acknowledge EPSRC grant EP/M023877/1 and MRC CiC at University of Birmingham.

Institutional Review Board Statement: Not applicable.

Informed Consent Statement: Not applicable.

Data Availability Statement: Data is contained within the article or Supplementary Materials.

Acknowledgments: This study acknowledges the support from University of Birmingham, UK and CARA. GP would like to thank EPSRC (grant number EP/M023877/1) for funding. The authors would like to thank Sherif Mohamad for antibacterial training and thank Justyna Hofmanova and Gabor Dravavolgyi for rheology training.

Conflicts of Interest: The authors declare no conflict of interest.

\section{References}

1. Silber, J.S.; Anderson, D.G.; Daffner, S.D.; Brislin, B.T.; Leland, J.M.; Hilibrand, A.S.; Vaccaro, A.R.; Albert, T.J. Donor site morbidity after anterior iliac crest bone harvest for single-level anterior cervical discectomy and fusion. Spine 2003, 28, 134-139. [CrossRef] [PubMed]

2. VandeVord, P.J.; Nasser, S.; Wooley, P.H. Immunological responses to bone soluble proteins in recipients of bone allografts. J. Orthop. Res. 2005, 23, 1059-1064. [CrossRef] [PubMed]

3. Fishman, J.A.; Greenwald, M.A.; Grossi, P. Transmission of Infection with Human Allografts: Essential Considerations in Donor Screening. Clin. Infect. Dis. 2012, 55, 720-727. [CrossRef] [PubMed]

4. Al-Namnam, N.; Jayash, S.N. Recent advances in bone graft substitute for oral and maxillofacial applications: A review. Int. J. Biosci. 2019, 15, 70-94.

5. Oryan, A.; Alidadi, S.; Moshiri, A.; Maffulli, N. Bone regenerative medicine: Classic options, novel strategies, and future directions. J. Orthop. Surg. Res. 2014, 9, 18. [CrossRef]

6. Xue, K.; Wang, X.; Yong, P.W.; Young, D.J.; Wu, Y.-L.; Li, Z.; Loh, X.J. Hydrogels as Emerging Materials for Translational Biomedicine. Adv. Ther. 2019, 2, 1800088. [CrossRef]

7. Li, X.; Su, X. Multifunctional smart hydrogels: Potential in tissue engineering and cancer therapy. J. Mater. Chem. B 2018, 6, 4714-4730. [CrossRef]

8. Tan, H.; Marra, K.G. Injectable, Biodegradable Hydrogels for Tissue Engineering Applications. Materials 2010, 3, $1746-1767$. [CrossRef]

9. Lee, J.H. Injectable hydrogels delivering therapeutic agents for disease treatment and tissue engineering. Biomater. Res. 2018, 22, 1-14. [CrossRef] 
10. Catoira, M.C.; Fusaro, L.; Di Francesco, D.; Ramella, M.; Boccafoschi, F. Overview of natural hydrogels for regenerative medicine applications. J. Mater. Sci. Mater. Med. 2019, 30, 1-10. [CrossRef]

11. Palma, P.J.; Ramos, J.C.; Martins, J.B.; Diogenes, A.; Figueiredo, M.H.; Ferreira, P.; Viegas, C.; Santos, J.M. Histologic evaluation of regenerative endodontic procedures with the use of chitosan scaffolds in immature dog teeth with apical per-iodontitis. J. Endod. 2017, 43, 1279-1287. [CrossRef] [PubMed]

12. Jabbari, E.; Leijten, J.; Xu, Q.; Khademhosseini, A. The matrix reloaded: The evolution of regenerative hydrogels. Mater. Today 2016, 19, 190-196. [CrossRef]

13. Billiet, T.; Vandenhaute, M.; Schelfhout, J.; Van Vlierberghe, S.; Dubruel, P. A review of trends and limitations in hydro-gel-rapid prototyping for tissue engineering. Biomaterials 2012, 33, 6020-6041. [CrossRef] [PubMed]

14. Huang, W.-C.; Lee, T.-J.; Hsiao, C.-S.; Chen, S.-Y.; Liu, D.-M. Characterization and drug release behavior of chip-like am-phiphilic chitosan-silica hybrid hydrogel for electrically modulated release of ethosuximide: An in vitro study. J. Mater. Chem. 2011, 21, 16077-16085. [CrossRef]

15. Parlato, M.; Reichert, S.; Barney, N.; Murphy, W.L. Poly (ethylene glycol) hydrogels with adaptable mechanical and deg-radation properties for use in biomedical applications. Macromol. Biosci. 2014, 14, 687-698. [CrossRef]

16. Metters, A.; Anseth, K.; Bowman, C. Fundamental studies of a novel, biodegradable PEG-b-PLA hydrogel. Polymers 2000, 41, 3993-4004. [CrossRef]

17. Bryant, S.J.; Anseth, K.S. Hydrogel properties influence ECM production by chondrocytes photoencapsulated in poly (eth-ylene glycol) hydrogels. J. Biomed. Mater. Res. Off. J. Soc. Biomater. Jpn. Soc. Biomater. 2002, 59, 63-72. [CrossRef] [PubMed]

18. Tibbitt, M.W.; Anseth, K.S. Hydrogels as extracellular matrix mimics for 3D cell culture. Biotechnol. Bioeng. 2009, 103, 655-663. [CrossRef]

19. Otvos, L., Jr.; Wade, J.D. Current challenges in peptide-based drug discovery. Front. Chem. 2014, 2, 62. [CrossRef]

20. Yadav, N.; Chauhan, M.K.; Chauhan, V.S. Short to ultrashort peptide-based hydrogels as a platform for biomedical appli-cations. Biomater. Sci. 2020, 8, 84-100. [CrossRef]

21. Mir, S.H.; Nagahara, L.A.; Thundat, T.; Tabari, P.M.-; Furukawa, H.; Khosla, A. Review-Organic-Inorganic Hybrid Functional Materials: An Integrated Platform for Applied Technologies. J. Electrochem. Soc. 2018, 165, B3137-B3156. [CrossRef]

22. Wang, D.; Romer, F.; Connell, L.; Walter, C.; Saiz, E.; Yue, S.; Lee, P.D.; McPhail, D.S.; Hanna, J.V.; Jones, J.R. Highly flexible silica/chitosan hybrid scaffolds with oriented pores for tissue regeneration. J. Mater. Chem. B 2015, 3, 7560-7576. [CrossRef]

23. Mondal, D. Covalently Crosslinked Organic/Inorganic Hybrid Biomaterials for Bone Tissue Engineering Applications. Ph.D. Thesis, Western University, London, ON, Canada, 2018.

24. Jones, J.R. Review of bioactive glass: From Hench to hybrids. Acta Biomater. 2013, 9, 4457-4486. [CrossRef]

25. Murphy, C.; O'Brien, F.; Little, D.; Schindeler, A. Cell-scaffold interactions in the bone tissue engineering triad. Eur. Cells Mater. 2013, 26, 120-132. [CrossRef] [PubMed]

26. Poologasundarampillai, G.; Yu, B.; Tsigkou, O.; Valliant, E.; Yue, S.; Lee, P.; Hamilton, R.; Stevens, M.; Kasuga, T.; Jones, J. Bioactive silica-poly ( $\gamma$-glutamic acid) hybrids for bone regeneration: Effect of covalent coupling on dissolution and me-chanical properties and fabrication of porous scaffolds. Soft Matter 2012, 8, 4822-4832. [CrossRef]

27. Poologasundarampillai, G.; Yu, B.; Tsigkou, O.; Wang, D.; Romer, F.; Bhakhri, V.; Giuliani, F.; Stevens, M.M.; McPhail, D.S.; Smith, M.E.; et al. Poly ( $\gamma$-glutamic acid)/Silica Hybrids with Calcium Incorporated in the Silica Network by Use of a Calcium Alkoxide Precursor. Chem.-A Eur. J. 2014, 20, 8149-8160. [CrossRef]

28. Soares, D.C.F.; Domingues, S.C.; Viana, D.B.; Tebaldi, M.L. Polymer-hybrid nanoparticles: Current advances in biomedical applications. Biomed. Pharmacother. 2020, 131, 110695. [CrossRef]

29. Ates, B.; Koytepe, S.; Balcioglu, S.; Ulu, A.; Gurses, C. Biomedical applications of hybrid polymer composite materials. In Hybrid Polymer Composite Materials; Elsevier BV: Amsterdam, The Netherlands, 2017; pp. 343-408.

30. Petit, L.; Bouteiller, L.; Brûlet, A.; Lafuma, A.F.; Hourdet, D. Responsive Hybrid Self-Assemblies in Aqueous Media. Langmuir 2007, 23, 147-158. [CrossRef]

31. Lin, W.-C.; Fan, W.; Marcellan, A.; Hourdet, D.; Creton, C. Large strain and fracture properties of poly (dimethylacryla-mide)/silica hybrid hydrogels. Macromolecules 2010, 43, 2554-2563. [CrossRef]

32. Kim, K.J.; Joe, Y.A.; Kim, M.K.; Lee, S.J.; Ryu, Y.H.; Cho, D.-W.; Rhie, J.W. Silica nanoparticles increase human adipose tissuederived stem cell proliferation through ERK1/2 activation. Int. J. Nanomed. 2015, 10, 2261. [CrossRef]

33. Shie, M.-Y.; Ding, S.-J.; Chang, H.-C. The role of silicon in osteoblast-like cell proliferation and apoptosis. Acta Biomater. 2011, 7, 2604-2614. [CrossRef]

34. Roldo, M.; Hornof, M.; Caliceti, P.; Bernkop-Schnürch, A. Mucoadhesive thiolated chitosans as platforms for oral controlled drug delivery: Synthesis and in vitro evaluation. Eur. J. Pharm. Biopharm. 2004, 57, 115-121. [CrossRef]

35. Sreenivas, S.; Pai, K. Thiolated Chitosans: Novel Polymers for Mucoadhesive Drug Delivery-A Review. Trop. J. Pharm. Res. 2008, 7, 1077-1088. [CrossRef]

36. Andreas, B.; Hornof, M.; Zoidl, T. Thiolated polymers-thiomers: Modification of chitosan with 2-iminothiolane. Int. J. Pharm 2003, 260, 229-237.

37. Langoth, N.; Guggi, D.; Pinter, Y.; Andreas, B. Thiolated chitosan: In vitro evaluation of its permeation enhancing properties. J. Control. Rel. 2004, 94, 177. 
38. M Ways, T.M.; Lau, W.M.; Khutoryanskiy, V.V. Chitosan and its derivatives for application in mucoadhesive drug delivery systems. Polymers 2018, 10, 267. [CrossRef]

39. Poologasundarampillai, G.; Ionescu, C.; Tsigkou, O.; Murugesan, M.; Hill, R.G.; Stevens, M.M.; Hanna, J.V.; Smith, M.E.; Jones, J.R. Synthesis of bioactive class II poly( $\gamma$-glutamic acid)/silica hybrids for bone regeneration. J. Mater. Chem. 2010, 20, 8952-8961. [CrossRef]

40. Poologasundarampillai, G.; Yu, B.; Jones, J.; Kasuga, T. Electrospun silica/PLLA hybrid materials for skeletal regeneration. Soft. Matter. 2011, 7, 10241-10251. [CrossRef]

41. Mahony, O.; Tsigkou, O.; Ionescu, C.; Minelli, C.; Ling, L.; Hanly, R.; Smith, M.E.; Stevens, M.M.; Jones, J.R. Silica-Gelatin Hybrids with Tailorable Degradation and Mechanical Properties for Tissue Regeneration. Adv. Funct. Mater. 2010, 20, 3835-3845. [CrossRef]

42. Bounor-Legaré, V.; Ferreira, I.; Verbois, A.; Cassagnau, P.; Michel, A. New transesterification between ester and alkoxysilane groups: Application to ethylene-co-vinyl acetate copolymer crosslinking. Polymers 2002, 43, 6085-6092. [CrossRef]

43. Gill, I.; Ballesteros, A.O. Encapsulation of Biologicals within Silicate, Siloxane, and Hybrid Sol-Gel Polymers: An Efficient and Generic Approach. J. Am. Chem. Soc. 1998, 120, 8587-8598. [CrossRef]

44. Da Silva, S.; de Albuquerque, N.; de Almeida, R.; de Abreu, F. Synthesis and charaterization of silica-based aldehyde chitosan hybrid material for biodiesel purification. Materials 2017, 10, 1132. [CrossRef] [PubMed]

45. Martins, T.; Moreira, C.D.; Costa-Júnior, E.S.; Pereira, M.M. In vitro degradation of chitosan composite foams for biomedical applications and effect of bioactive glass as a crosslinker. Biomed. Glasses 2018, 4, 45-56. [CrossRef]

46. Tan, W.; Li, Q.; Dong, F.; Zhang, J.; Luan, F.; Wei, L.; Chen, Y.; Guo, Z. Novel cationic chitosan derivative bearing 1,2,3-triazolium and pyridinium: Synthesis, characterization, and antifungal property. Carbohydr. Polym. 2018, 182, 180-187. [CrossRef] [PubMed]

47. Badawy, M.E.; Rabea, E.I.; Taktak, N.E. Antimicrobial and inhibitory enzyme activity of N-(benzyl) and quaternary N-(benzyl) chitosan derivatives on plant pathogens. Carbohydr. Polym. 2014, 111, 670-682. [CrossRef]

48. Li, R.; Deng, L.; Cai, Z.; Zhang, S.; Wang, K.; Li, L.; Ding, S.; Zhou, C. Liposomes coated with thiolated chitosan as drug carriers of curcumin. Mater. Sci. Eng. C 2017, 80, 156-164. [CrossRef]

49. Connell, L.S.; Romer, F.; Suárez, M.; Valliant, E.M.; Zhang, Z.; Lee, P.D.; Smith, M.E.; Hanna, J.V.; Jones, J.R. Chemical characterisation and fabrication of chitosan-silica hybrid scaffolds with 3-glycidoxypropyl trimethoxysilane. J. Mater. Chem. $B$ 2014, 2, 668-680. [CrossRef]

50. Oleyaei, S.A.; Razavi, S.M.A.; Mikkonen, K.S. Novel nanobiocomposite hydrogels based on sage seed gum-laponite: Physicochemical and rheological characterization. Carbohydr. Polym. 2018, 192, 282-290. [CrossRef]

51. Kharkar, P.M.; Kiick, K.L.; Kloxin, A.M. Designing degradable hydrogels for orthogonal control of cell microenvironments. Chem. Soc. Rev. 2013, 42, 7335-7372. [CrossRef] [PubMed]

52. El Kadib, A.; Bousmina, M. Chitosan bio-based organic-inorganic hybrid aerogel microspheres. Chem.-A Eur. J. 2012, 18, 8264-8277. [CrossRef]

53. Pandey, S.; Mishra, S.B. Organic-inorganic hybrid of chitosan/organoclay bionanocomposites for hexavalent chromium uptake. J. Colloid Interface Sci. 2011, 361, 509-520. [CrossRef]

54. Ebisike, K.; Okoronkwo, A.E.; Alaneme, K.K. Synthesis and characterization of Chitosan-silica hybrid aerogel using sol-gel method. J. King Saud Univ.-Sci. 2020, 32, 550-554. [CrossRef]

55. Park, J.-U.; Jeong, S.-H.; Song, E.-H.; Song, J.; Kim, H.-E.; Kim, S. Acceleration of the healing process of full-thickness wounds using hydrophilic chitosan-silica hybrid sponge in a porcine model. J. Biomater. Appl. 2018, 32, 1011-1023. [CrossRef] [PubMed]

56. Ma, I.W.; Ammar, S.; Bashir, S.; Selvaraj, M.; Assiri, M.A.; Ramesh, K.; Ramesh, S. Preparation of Hybrid Chitosan/Silica Composites via Ionotropic Gelation and Its Electrochemical Impedance Studies. Prog. Org. Coat. 2020, 145, 105679. [CrossRef]

57. Anitha, A.; Deepa, N.; Chennazhi, K.; Nair, S.; Tamura, H.; Jayakumar, R. Development of mucoadhesive thiolated chitosan nanoparticles for biomedical applications. Carbohydr. Polym. 2011, 83, 66-73. [CrossRef]

58. Liu, Y.-L.; Su, Y.-H.; Lai, J.-Y. In situ crosslinking of chitosan and formation of chitosan-silica hybrid membranes with using $\gamma$-glycidoxypropyltrimethoxysilane as a crosslinking agent. Polymers 2004, 45, 6831-6837. [CrossRef]

59. Chao, A.-C. Preparation of porous chitosan/GPTMS hybrid membrane and its application in affinity sorption for tyrosinase purification with Agaricus bisporus. J. Membr. Sci. 2008, 311, 306-318. [CrossRef]

60. Shirosaki, Y.; Tsuru, K.; Hayakawa, S.; Osaka, A.; Lopes, M.A.; Santos, J.D.; Costa, M.A.; Fernandes, M.H. Physical, chemical and in vitro biological profile of chitosan hybrid membrane as a function of organosiloxane concentration. Acta Biomater. 2009, 5, 346-355. [CrossRef] [PubMed]

61. Varghese, J.G.; Karuppannan, R.S.; Kariduraganavar, M.Y. Development of Hybrid Membranes Using Chitosan and Silica Precursors for Pervaporation Separation of Water + Isopropanol Mixtures. J. Chem. Eng. Data 2010, 55, 2084-2092. [CrossRef]

62. Bernkop-Schnürch, A.; Guggi, D.; Pinter, Y. Thiolated chitosans: Development and in vitro evaluation of a mucoadhesive, permeation enhancing oral drug delivery system. J. Control. Release 2004, 94, 177-186. [CrossRef]

63. Depan, D.; Kumar, B.; Singh, R.P. Preparation and characterization of novel hybrid of chitosan-g-PDMS and sodium montmorrilonite. J. Biomed. Mater. Res. Part B Appl. Biomater. 2008, 84B, 184-190. [CrossRef]

64. Toskas, G.; Cherif, C.; Hund, R.-D.; Laourine, E.; Mahltig, B.; Fahmi, A.; Heinemann, C.; Hanke, T. Chitosan(PEO)/silica hybrid nanofibers as a potential biomaterial for bone regeneration. Carbohydr. Polym. 2013, 94, 713-722. [CrossRef] 
65. Gabrielli, L.; Connell, L.; Russo, L.; Jiménez-Barbero, J.; Nicotra, F.; Cipolla, L.; Jones, J.R. Exploring GPTMS reactivity against simple nucleophiles: Chemistry beyond hybrid materials fabrication. RSC Adv. 2014, 4, 1841-1848. [CrossRef]

66. Gabrielli, L.; Russo, L.; Poveda, A.; Jones, J.R.; Nicotra, F.; Jiménez-Barbero, J.; Cipolla, L. Epoxide Opening versus Silica Condensation during Sol-Gel Hybrid Biomaterial Synthesis. Chem.-A Eur. J. 2013, 19, 7856-7864. [CrossRef]

67. Wang, D.; Liu, W.; Feng, Q.; Dong, C.; Liu, Q.; Duan, L.; Huang, J.; Zhu, W.; Li, Z.; Xiong, J.; et al. Effect of inorganic/organic ratio and chemical coupling on the performance of porous silica/chitosan hybrid scaffolds. Mater. Sci. Eng. C 2017, 70, 969-975. [CrossRef]

68. Vårum, K.M.; Myhr, M.M.; Hjerde, R.J.; Smidsrød, O. In vitro degradation rates of partially N-acetylated chitosans in human serum. Carbohydr. Res. 1997, 299, 99-101. [CrossRef]

69. Lončarević, A.; Ivanković, M.; Rogina, A. Lysozyme-induced degradation of chitosan: The characterisation of degraded chi-tosan scaffolds. J. Tissue Repair Regen. 2017, 1, 12.

70. Freier, T.; Koh, H.S.; Kazazian, K.; Shoichet, M.S. Controlling cell adhesion and degradation of chitosan films by N-acetylation. Biomaterials 2005, 26, 5872-5878. [CrossRef] [PubMed]

71. Shirosaki, Y.; Hirai, M.; Hayakawa, S.; Fujii, E.; Lopes, M.A.; Santos, J.D.; Osaka, A. Preparation and in vitro cytocompatibility of chitosan-Siloxane hybrid hydrogels. J. Biomed. Mater. Res. Part A 2015, 103, 289-299. [CrossRef] [PubMed]

72. Xu, B.; Liu, Y.; Wang, L.; Ge, X.; Fu, M.; Wang, P.; Wang, Q. High-Strength Nanocomposite Hydrogels with Swelling-Resistant and Anti-Dehydration Properties. Polymers 2018, 10, 1025. [CrossRef] [PubMed]

73. Stefanov, I.; Hinojosa-Caballero, D.; Maspoch, S.; Hoyo, J.; Tzanov, T. Enzymatic synthesis of a thiolated chitosan-based wound dressing crosslinked with chicoric acid. J. Mater. Chem. B 2018, 6, 7943-7953. [CrossRef] [PubMed]

74. Weng, L.; Chen, X.; Chen, W. Rheological Characterization of in Situ Crosslinkable Hydrogels Formulated from Oxidized Dextran and N-Carboxyethyl Chitosan. Biomacromolecules 2007, 8, 1109-1115. [CrossRef] [PubMed]

75. Hatefi, A.; Amsden, B. Biodegradable injectable in situ forming drug delivery systems. J. Control. Release 2002, 80, 9-28. [CrossRef]

76. Hou, Q.; Paul, A.; Shakesheff, K.M. Injectable scaffolds for tissue regeneration. J. Mater. Chem. 2004, 14, 1915-1923. [CrossRef]

77. Moura, M.J.; Figueiredo, M.M.L.; Gil, M.H. Rheological Study of Genipin Cross-Linked Chitosan Hydrogels. Biomacromolecules 2007, 8, 3823-3829. [CrossRef]

78. Chenite, A.; Chaput, C.; Wang, D.; Combes, C.; Buschmann, M.; Hoemann, C.; Leroux, J.; Atkinson, B.; Binette, F.; Selmani, A. Novel injectable neutral solutions of chitosan form biodegradable gels in situ. Biomaterials 2000, 21, 2155-2161. [CrossRef]

79. Alghooneh, A.; Razavi, S.M.A.; Behrouzian, F. Rheological characterization of hydrocolloids interaction: A case study on sage seed gum-xanthan blends. Food Hydrocoll. 2017, 66, 206-215. [CrossRef]

80. Vigilato, M.Á.; Horn, M.; Martins, V.C.A.; Plepis, A.M.D.G. Rheological study of gels based on chitosan and carbon nanotubes. Braz. J. Therm. Anal. 2015, 4, 35-38. [CrossRef]

81. Choi, B.Y.; Chalisserry, E.P.; Kim, M.H.; Kang, H.W.; Choi, I.-W.; Nam, S.Y. The Influence of Astaxanthin on the Proliferation of Adipose-derived Mesenchymal Stem Cells in Gelatin-Methacryloyl (GelMA) Hydrogels. Materials 2019, 12, 2416. [CrossRef]

82. Karvinen, J.; Ihalainen, T.O.; Calejo, M.T.; Jönkkäri, I.; Kellomäki, M. Characterization of the microstructure of hydrazone crosslinked polysaccharide-based hydrogels through rheological and diffusion studies. Mater. Sci. Eng. C 2019, 94, 1056-1066. [CrossRef]

83. Prasanth Koppolu, B.; Smith, S.G.; Ravindranathan, S.; Jayanthi, S.; Kumar, T.K.S.; Zaharoff, D.A. Controlling chitosan-based encapsulation for protein and vaccine delivery. Biomaterials 2014, 35, 4382-4389. [CrossRef] [PubMed]

84. Zhao, H.; Lin, Z.Y.; Yildirimer, L.; Dhinakar, A.; Zhao, X.; Wu, J. Polymer-based nanoparticles for protein delivery: Design, strategies and applications. J. Mater. Chem. B 2016, 4, 4060-4071. [CrossRef] [PubMed]

85. Pernodet, N.; Rafailovich, M.; Sokolov, J.; Xu, D.; Yang, N.L.; McLeod, K. Fibronectin fibrillogenesis on sulfonated poly-styrene surfaces. J. Biomed. Mater. Res. Part A Off. J. Soc. Biomater. Jpn. Soc. Biomater. Aust. Soc. Biomater. Korean Soc. Biomater. 2003, 64, 684-692.

86. Jeworrek, C.; Hollmann, O.; Steitz, R.; Winter, R.; Czeslik, C. Interaction of IAPP and Insulin with Model Interfaces Studied Using Neutron Reflectometry. Biophys. J. 2009, 96, 1115-1123. [CrossRef] [PubMed]

87. Jayash, S.N.; Hashim, N.M.; Misran, M.; Baharuddin, N. Formulation and in vitro and in vivo evaluation of a new osteoprotegerin-chitosan gel for bone tissue regeneration. J. Biomed. Mater. Res. Part A 2017, 105, 398-407. [CrossRef]

88. Jahromi, M.Z.; Ranjbarian, P.; Shiravi, S. Cytotoxicity Evaluation of Iranian Propolis and Calcium Hydroxide on Dental Pulp Fibroblasts. J. Dent. Res. Dent. Clin. Dent. Prospect. 2014, 8, 130-133. [CrossRef]

89. Cai, Y.; Che, J.; Yuan, M.; Shi, X.; Chen, W.; Yuan, W.-E. Effect of glycerol on sustained insulin release from PVA hydrogels and its application in diabetes therapy. Exp. Ther. Med. 2016, 12, 2039-2044. [CrossRef]

90. Puri, S.; Kallinteri, P.; Higgins, S.; Hutcheon, G.A.; Garnett, M.C. Drug incorporation and release of water soluble drugs from novel functionalised poly(glycerol adipate) nanoparticles. J. Control. Release 2008, 125, 59-67. [CrossRef]

91. McKinnon, D.D.; Domaille, D.W.; Cha, J.N.; Anseth, K.S. Biophysically defined and cytocompatible covalently adaptable networks as viscoelastic 3D cell culture systems. Adv. Mater. 2014, 26, 865-872. [CrossRef]

92. Palma, P.; Matos, S.; Ramos, J.; Guerra, F.; Figueiredo, M.; Kauser, J. New formulations for space provision and bone re-generation. Biodental Eng. 2010, I, 71-76.

93. Li, J.; Mooney, D.J. Designing hydrogels for controlled drug delivery. Nat. Rev. Mater. 2016, 1, 1-17. [CrossRef] [PubMed] 


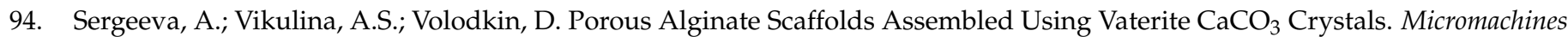
2019, 10, 357. [CrossRef]

95. Song, Z.; Borgwardt, L.; Høiby, N.; Wu, H.; Sørensen, T.S.; Borgwardt, A. Prosthesis infections after orthopedic joint re-placement: The possible role of bacterial biofilms. Orthop. Rev. 2013, 5, 65-71. [CrossRef] [PubMed]

96. Wu, C.; Sun, J.; Lu, Y.; Wu, T.; Pang, J.; Hu, Y. In situ self-assembly chitosan/ $\varepsilon$-polylysine bionanocomposite film with enhanced antimicrobial properties for food packaging. Int. J. Biol. Macromol. 2019, 132, 385-392. [CrossRef] [PubMed]

97. Costa, F.; Sousa, D.; Parreira, P.; Lamghari, M.; Gomes, P.; Martins, M.C.L. N-acetylcysteine-functionalized coating avoids bacterial adhesion and biofilm formation. Sci. Rep. 2017, 7, 1-13. [CrossRef]

98. Brook, M.A.; Chen, Y.; Guo, K.; Zhang, Z.; Brennan, J.D. Sugar-modified silanes: Precursors for silica monoliths. J. Mater. Chem. 2004, 14, 1469-1479. [CrossRef]

99. Brook, M.A.; Chen, Y.; Guo, K.; Zhang, Z.; Jin, W.; Deisingh, A.; Cruz-Aguado, J.; Brennan, J.D. Proteins Entrapped in Silica Monoliths Prepared from Glyceroxysilanes. J. Sol-Gel Sci. Technol. 2004, 31, 343-348. [CrossRef]

100. Hartmann, S.; Brandhuber, D.; Hüsing, N. Glycol-Modified Silanes: Novel Possibilities for the Synthesis of Hierarchically Organized (Hybrid) Porous Materials. Acc. Chem. Res. 2007, 40, 885-894. [CrossRef]

101. Pipattanawarothai, A.; Suksai, C.; Srisook, K.; Trakulsujaritchok, T. Non-cytotoxic hybrid bioscaffolds of chitosan-silica: Sol-gel synthesis, characterization and proposed application. Carbohydr. Polym. 2017, 178, 190-199. [CrossRef]

102. Kurakula, M.; Naveen, N.R. In situ gel loaded with chitosan-coated simvastatin nanoparticles: Promising delivery for ef-fective anti-proliferative activity against tongue carcinoma. Marine Drugs 2020, 18, 201. [CrossRef]

103. Kurakula, M.; Naveen, N.R.; Patel, B.; Manne, R.; Patel, D.B. Preparation, optimization and evaluation of chitosan-based avanafil nanocomplex utilizing antioxidants for enhanced neuroprotective effect on PC12 cells. Gels 2021, 7, 96. [CrossRef] [PubMed]

104. Jayash, S.N.; Hashim, N.M.; Misran, M.; Baharuddin, N. In vitro evaluation of osteoprotegerin in chitosan for potential bone defect applications. PeerJ 2016, 4, e2229. [CrossRef] [PubMed]

105. Jayash, S.N.; Hashim, N.M.; Misran, M.; Ibrahim, N.; AL-Namnam, N.M.; Baharuddin, N. Analysis on efficacy of chitosan-based gel on bone quality and quantity. Front. Mater. 2021, 8, 46. [CrossRef]

106. ISO 10993-12. 2012 Biological Evaluation of Medical Devices-Part 12: Sample Preparation and Reference Materials; International Organization for Standardization: Geneva, Switzerland, 2012.

107. Trujillo, S.; Pérez-Román, E.; Kyritsis, A.; Gómez Ribelles, J.L.; Pandis, C. Organic-inorganic bonding in chitosan-silica hybrid networks: Physical properties. J. Polym. Sci. Part B Polym. Phys. 2015, 53, 1391-1400. [CrossRef]

108. Duan, B.; Hockaday, L.A.; Kang, K.H.; Butcher, J.T. 3D bioprinting of heterogeneous aortic valve conduits with algi-nate/gelatin hydrogels. J. Biomed. Mater. Res. Part A 2013, 101, 1255-1264. [CrossRef]

109. Naveen, N.R.; Kurakula, M.; Gowthami, B. Process optimization by response surface methodology for preparation and evaluation of methotrexate loaded chitosan nanoparticles. Mater. Today Proc. 2020, 33, 2716-2724. [CrossRef]

110. Koch, M.; Włodarczyk-Biegun, M.K. Faithful scanning electron microscopic (SEM) visualization of 3D printed alginate-based scaffolds. Bioprinting 2020, 20, e00098. [CrossRef] 